CIHM Microfiche Series (Monographs)
ICMH

Collection de microfiches (monographies)
The

copy

may

the

signi

chec

唯

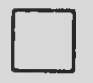

$\square$
$\square$
$\square$
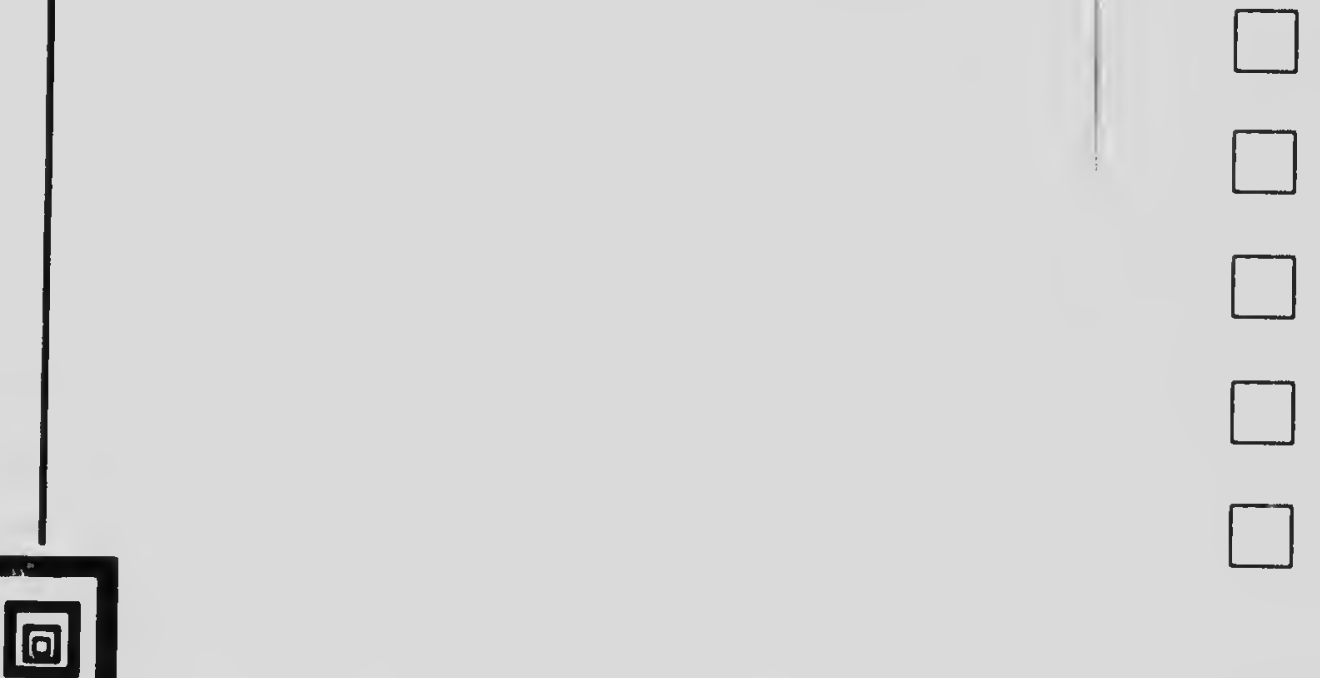

Canadian Institute for Historical Microreproductions / Institut canadien de microreproductions historiques
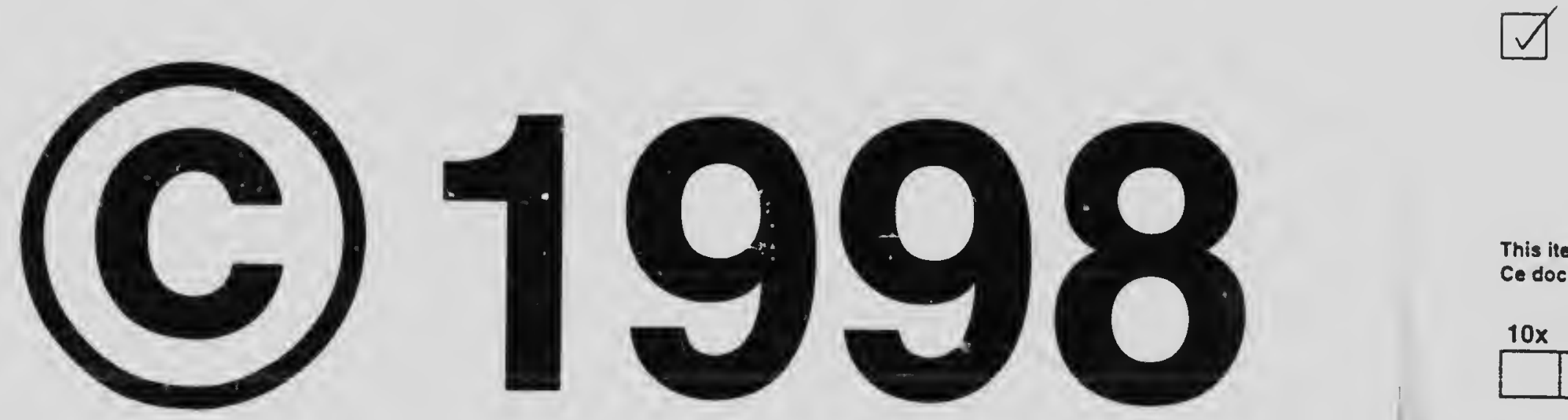

This ite

Ce doc:

$10 x$ 


\section{Technical and Bibliographic Notes / Notes techniques et bibliographiques}

The Institute has attempted to obtain the best original copy available for filming. Features of this copy which may be bibliographically unique, which may alter any of the images in the reproduction, or which may significantly change the usual method of filming are checked below.

\section{$\checkmark$}

Coloured covers /

Couverture de couleur

Covers damaged /

Cnuverture endommagée

Covers restored and/or laminated /

Couverture restaurée etou pelliculée

Cover title missing / Le titre de cr verture manque

Coloured maps / Cartes géographiques en couleur

Coloured ink (i.e. other than blue or black) /

Encre de couleur (i.e. autre que bleve ou noire)

Coloured plates and/or illustrations /

Planches etou illustrations en couleur

Bound with other material /

Relié avec d'autres documents

Only edition available /

Seule édition disponible

Tight binding $r$ dy cause shadows or distortion along interior margin / La reliure serrée peut causer de l'ombre ou de la distorsion le long de la marge intérieure.

Blank leaves added during restorations may appear within the text. Whenever possible, these have been omitted from filming / II se peut que certaines pages blanches ajoutées lors d'une restauration apparaissent dans le texte, mais, lorsque cela était possible, ces pages n'ont pas été filmées.
L'Institut a microfilmé le meilleur exemplaire quil lui a été possible de se procurer. Les détails de cet exemplaire qui sont peut-être uniques du point de vue bibliographique, qui peuvent modifier une image reproduite, ou qui peuvent exiger une modification dans la méthode normale de filmage sont indiqués ci-dessous.

Coloured pages / Pages de couleur

Pages damaged / Pages endommagées

Pages restored and/or laminated /

Pages restaurées etou pelliculées

Pages discoloured, stained or foxed /

Pages décolorées, tachetées ou piquées

Pages detached/Pages détachées

Showthrough / Transparence

Quality of print varies /

Qualité inégale de l'impression

Includes supplementary material /

Comprend du matériel supplémentaire

Pages wholly or partially obscured by errata slips, tissues, etc., have been refilmed to ensure the best possible image / Les pages totalement ou partiellement obscurcies par un fe jillet d'errata, une pelure, elc., ont été filmées à nouveau de façon à obtenir la meilleure image possible.

Opposing pages with varying colouration or discolourations are filmed twice to ensure the best possible image / Les pages s'opposant ayant des colorations variables ou des décolorations sont filmées deux fois afin d'obtenir la meilleure image. possible.

Additional comments /

Commentaires supplémentaires:

Pagination is as follows: p.[137]-144, [157]-164, 12-20.

This Item is filmed at the reduction ratio checked below I

Ce document est filmé au taux de réduction indiqué ci-dessous.

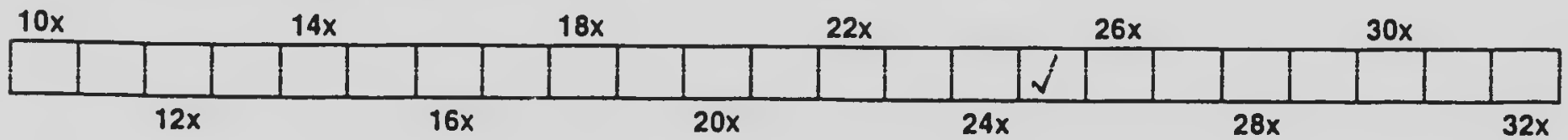


The copy filmed here hes been reproduced thenks to the generosity of:

\section{National Library of Canada}

The imeges eppeoring here ore the best quality possible considering the condition and legibility of the original copy and in keeping with the filming contrect speciflcotions.

Original copies in printed peper covere ere fllmed beginning with the front cover end ending on the latt page with a printed or illustrated impres. sion, of the beck cover when eppropriate. All other originol copies are filmod beginning on the first pege with o printed of illustreted impres. sion. and ending on the lest pege with a printed or illustroted impression.

The lest recorded frame on each microfiche shall contain the symbol $\rightarrow$ Imeening "CON. TINUED"), of the symbol $\nabla$ (meaning "END"). whichover applies.

Maps, pletes. charts, etc.. may be filmed et different reduction retios. Those too large to be entiroly included in one exposure ere filmed beginning in the upper lett hend corner. left to right and top to bottom. as meny frames es required. The following diegrams illustrete the mothod:
L'exempleire filmb fut reproduit grdes la góndrosito da:

Bibliothègue nationale du Canada

Les images suiventes ont bté reproduites evec le plus grend soin. compre tenu de le condision et de le nertet's de l'exempleire filmb, ot en conformite ovec les conditions du controt de filmage.

Les exemplaires origineux dont le couverture en pepief est imprimbe sont filmbs en commencent par le premier plet ot en terminant soit par la dernidre poge qui comporte une emprointe d'Impression ou d'illustration. soit per le second plat. selon le ces. Tous les eutres exemplaires originaux sont filmb en commencent por le premibre pege qui compore une emprointo d'impression ou d'illustrotion ot on torminent par le dernidre pege qui comporte une tolle emprointe.

Un des symboles suivents appereitre sup lo dernibre imege de cheque microfiche. selon le ces: lo symbole $\longrightarrow$ signifle "A SUIVRE". lo symbole $\nabla$ signifie "FIN".

Les corres, plenches. tableoux, otc., peuvent ètre filmbs des toux de roduction diffórents. Lorsque le document est trop grand poup biis reproduit on un soul clicht. il est filme partif de l'engle supbrieur gauche, de geuche d droite. et de haut en bas. en prenent le nombre d'images nucesseire. Les diegremmes suivents illustrent la mothode.
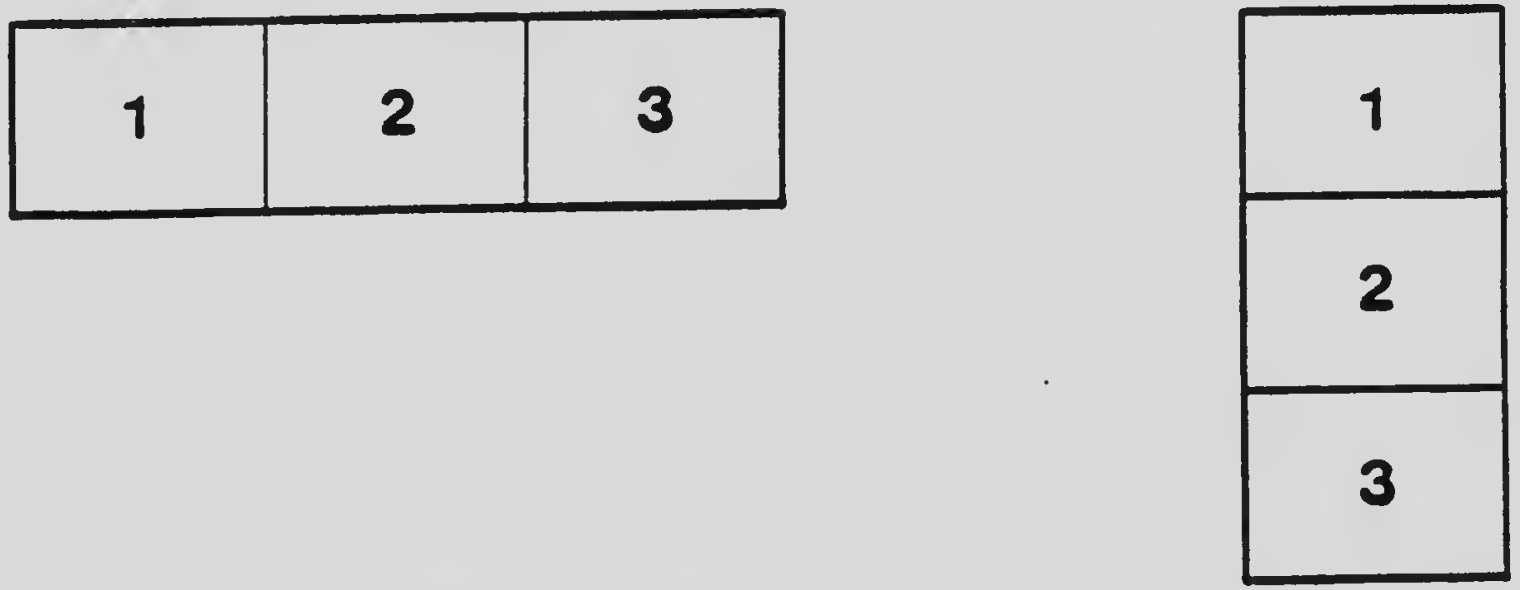

\begin{tabular}{|l|l|l|}
\hline 1 & 2 & 3 \\
\hline 4 & 5 & 6 \\
\hline
\end{tabular}


MICROCOPY RESOLUTION TEST CHART

ANSI and ISO TEST CHART No 2 ।
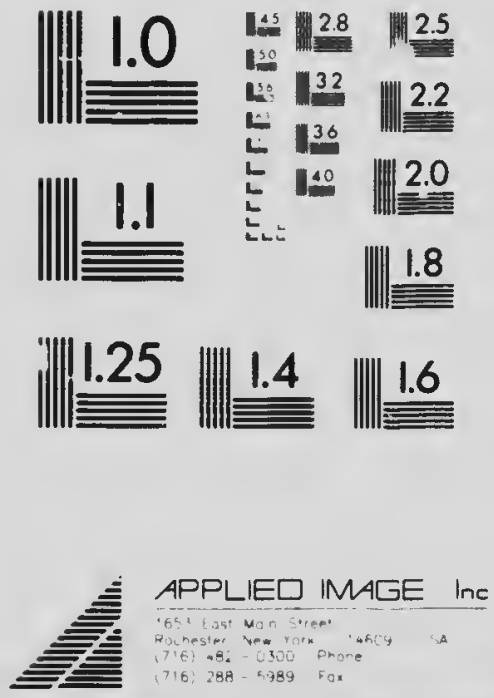


\section{Cumplingtín}

THE BIRDS OF SHOAL LAKE, MANITOBA. By P. A. TAVerner.

Reprinted from The Ottawa Naturalust, Vol XXXII, February, March, 1919, and The Canadian Field-Naturalust, Vol. XXXIII, April, 1919. 


\section{THE OTTAWA NATURALIST}

\section{THE BIRDS OF SHOAL LAKF, MANITOBA.*}

\section{By P. A. Taverner.}

Shoal Lake, Manitoba, lies some thiny-five miles a little east of north from the city of Winnipeg and approximately midway between the lower lobea of the two great lakes, Winnipeg and Manitoba. Though brought to the attention of ornithologists at an early date and later repeatedly visited by collectors, very little information has found its way into print regarding the details of its bird life.

Donald Gunn visited the lake in 1867, and his account ${ }^{\prime}$ is extensively quoted by Ernest F. T. Seton (Ernest E. Thompson or Ernest Seton Thompson) in his Birds of Western Manitoba." The same notes with additions appear in The Birds of Mamioba by the ame author and briefly summarized again in the bird part of his $F_{\text {auna of }} \mathrm{Manitoba}^{4}$ in which the nomenclature is brought up to date.

In 1891. Fred Dippie was in the adjoining locality of Raeburn. In 1893 and the following year Edward Arnold" and Walter Raine visited the lake itself. The latter casually mentions Shoal Lake in his Birds Nesting in Canada" but gives no details, and his only published account appears in the Oologist. Frank Chapman and E. T. Seton were on the lake in July, 1901 The former has a popular generalized account of his trip in his Camps and Cruises of an Ornithologist, ${ }^{*}$ and I am indebted to Mr. Seton for a copy of his original field notes which I have quoted freely in the following. By him I am informed that Mr Miller Christy, of

I'ubilsheil by por (ieolosical survey. Notes un an west of Lake li. innual Rogrort, s Annual Rogort, s. Asonlan Institution. for 1867 .

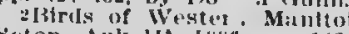

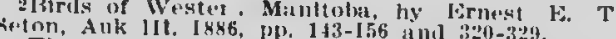
:The Isirels of Manitobe, $143-156$ and $320-324$.

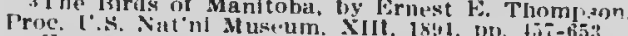
+ Finuna of Manituba. as it appeared in Gritis Ernest Thompson Seton, IIInnlpeg. 190y (repageil?) Assoclation Handhook, गI. I1-4i.

$\therefore$ Few Notes rrom Shoal Lake, Manitoba, Oolo-

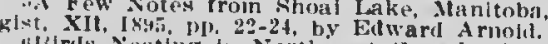
"ibiris Nesting in North west Canadi, hy Walter Raine. $18 ! 2$.

i.l Roukh Time collecting at Shoal Lake, Manttoba. Oulogist. XII, 18\%5, pp, 3-6, one plate, by Waiter IRaint.

citmps anil Cruises of An Ornithologist, by Frank
Broomfield, Fssex, Fngland, visited the vicinity in May, 1887, and a collection of birds he made :here is now in Seton's museum. June 27 to 29,1912 , Mr. Herbert K. Job and his son visited the south and west end of the lake looking for headquarters at which to obtain water bird's eggs for propagating purposes, but found the locality unsuited to their work. Mr. Job has kindly furnished mie with a copy of his notes. I have heard of several other observers having collected about the lake at various times, but reports from them are not available at the present writing. From the context most of these trips have been made to the southern extremity of the lake, or in the case of Gunn, 1867, along the west side as far north as the Narrows.

Prompted by these accounts-and desiring a representative collection of Manitoban material, the Biological Division of the Geological Survey, Canada, made an expedition to Shoal Lake the spring of 1917. The party consisted of Mr. C. H. Young and the writer. We arived at the C.N.R. station at Erinview, some four miles from the east side and about opposite the middle of the lower section of the lake, on May 16. Here we were fortunate in meeting $M r$. Frank Ward, who with his father and brother, lives on the lake shore. He transported us and our baggage to his farmstead and allowed us camping privileges in the immediate vicinity. The $W$ ard brothers proved to be unusually well informed sportsmen naturalists and we are indebied to them for many interesting notes and much valuable assistance during the course of our work. I heartily recommend them to all visiting naturalists.

On the map, Shoal Lake is indicated as being about thirty miles long north and south and ten miles in extreme width at the southern end. It is very irregularly shaped, with a constriction called the Narrows somewhat below the middle, forming practically two lakes divided by wide marshes through which winds a narrow creek-like channel. Both Chapman and Gunn describe the shores as composed of broad marshes with tall reeds in which 
water birds, grebes, ducks, and rails nested in immense numbers, and with stony islets in the lake populated ty nesting gulls, tern, pelicans, and cormorants. Today this description and outline are hardly recognizable. The water has fallen from eight to ten feet from its old level, as indicated by the old shore line still visible and the outline and conditions are greatly clianged. The Narrows are now high, diy hay ficlds and the creek channel is a dry ditch winding its way across two miles of open prairic cutting the lake into two separate bodies of water having no communication with one another. The surround, ng marshes have disappeared and in their place are broad reaches white with alkali crystals. The islets, deserted by their original tenants, are of considerable extent and with long sand and stone shoals reaching lowaid each other or toward the shore. Of the uxuriant growth of reeds nothing remains but the oot tops in the mud, prevented probably by increasing salinity from following the water in its retreat from the old shore-line. Of the vast numbers of birds that once treaded the mazes of the marsh praclically none remain but the few that are resiricted to the borders of the rapidly disappearing pools back from the shores.

A tradition from aboriginal sources asserts that the lake rises and falls regularly with a pericd of about fifteen years. Mr. Seton infornis me that "the waters of Shoal Lake, in common with all in Maniioba, have a fashion of ing and falling in periods of about seven years". However regular this rise and fall may be and what the pericd is, Shual Lake was high in 1867 when visited by Gunn, also in 1901 when Chapman and Seton were there. The Wards irrived on its shores about 1889 and Ward, Sr., declared that at that time the lake was low. It is evident from the reports of Arnold and Raine that the water was fairly high in 1894 and the Wards say that it reached its maximum about 1899 . It rises faster than it falls we are told. Whether the water will ever come back again to its old level remains for the future to show. Should it do so it will offer a remarkable irıceresting ecolegical study in investigating the effects of the cliange from highly alkaline to practically fresh water upon the contained and surrounding life. Before this chang takes place it is most desirable that a comprehensive study should be made of the present biological conditions as a basis of contrast with higher stages of water.

The lake has no important inlet and no outlet. The level is probably governed by the variation in annual rainfall extending over a series of years. The geological strata in which the lake lies is obviously porous and fissured with underground channels, as evidenced by changes in the water of near-by wells, but I have heard nothing of corre- sponding variations in level of the great lakes on eittier hand, so the local conditions are probably independent of them.

The surrounding country is prairie, liberally sprinkled with small clumps of bush. These clumps. called "bluffs" throughout the prairie provinces. range from mere spots of one or two low growing bushes to several acres of woodland and are occasionally a mile or more in their longest direction. They are usually very dense and sometimes all but impassable owing to undertrush, felled tops, or burnt trunks criss-crossed on the ground like jack straws. The edges, however, are sharply defined and beIween them runs the clear prairic, winding in and out, narrowing here to grassy lanes and widening there to green glades or broad meadows of vary. ing extent. All the woodland has suffered severely from fire. Grazing is the principal industry and the practice of burning the dead grass to induce a vigorous growth has not only tended to check the natural spread of the bluffs but has devastated many of them and groups of black skeleton trunks offend the eye more often than is desirable.

Most of the timber composing the bluffs is poplar with willow and other smaller shrubbery about the edges. In the largest bit of woodland in the neighbourhood of our camy, is a small stand of buiroak and on Maple Island, some five miles up the lake an island no longer-is a little maple (Sp.?) from which sugar used to be made. At the head of the upper lake, we are informed, considerable spruce or evergreen exists, but there is none in the parts visited by us. Poplar is the principal timber and that upon which the residents rely for general uses and for fuel. Viswed by eycs accustomed to eastern woodlands none of the growth is large-a ten-inch trunk is the maximum now seen. theugh occasional rotting stumps indicate that larger trees were more common before they fell to the axe of the early settlers. Now most of the growth is little more than pole size and rarely exceeds i heighi
of 40 feet.

Here and there, where the level of the land is lower, there have been marshes and the so-called red-rool bogs are common and muskeg occurs locally. Now, however, owing to the lowering of the water-line these are mostly dry except in sping and represented by damp areas with a few reed-like water grasses growing about the occasional watery spots which still persist. On my return in September I found that most of these hydrophytic evidences were obliterated and the usual hay grass was growing where in the spring cat tails and reeds had fourished. Occasional ponds had remained through the summer's drought, but few of these promised
to last long.

The spring of 1917 was late and as we passed 
over the prairie on our arrival our druver pointed to the grass just appearing thruugh the dead mat of last season's growth and remarked that it should be from 8 to 111 inches high. The poplars were just coming into leaf and the few oaks in the big woods behind the camp were still bare and gaunt. Though the day of our arrival was oppressively hot a change carne befere we had pitched camp and thereafter we had ruw, cold weather during most of our slay, with ice forming in the pails of water at night and towards the middle of June we were glad to have our stove in the working tent even throughout the warmth of the day.

The lake is subject to sudden cyclonic squalls and ligh winds. The former burst suddenly out of clear skics, whirl a clcud of clus: ard dibris high in the alr, and subside as quich." as they rise. On one necasion we saw where a '. . !der of consider- lake, but evidently are becoming fewer each yewr. Waders till vivited the shores, and birds wert fairly numerous. We had no difficulty in obtaining as many specimens as we were able to prepare. Unfortunately in shipping our collections to the Museum one box, containung the nuajority of our small birds, was lost in transit. Manitoba is the most eastern of the prairie provinces and one of the most important sub. jects of geographical distribution in Canada is the location of the meeting points of prairie forrss with those of the eastern woodlands. As the determina. ion of these fine subspecific points must bi based directly upon specimens the loss of them was serious and it was largely to replace them that Mr. Young reiurned to Shoal Lake the spring of 1918, spending from April 23 to October 2 on the same grounds we had occupied the previous spring.

He arrived just after the ice had broken up on

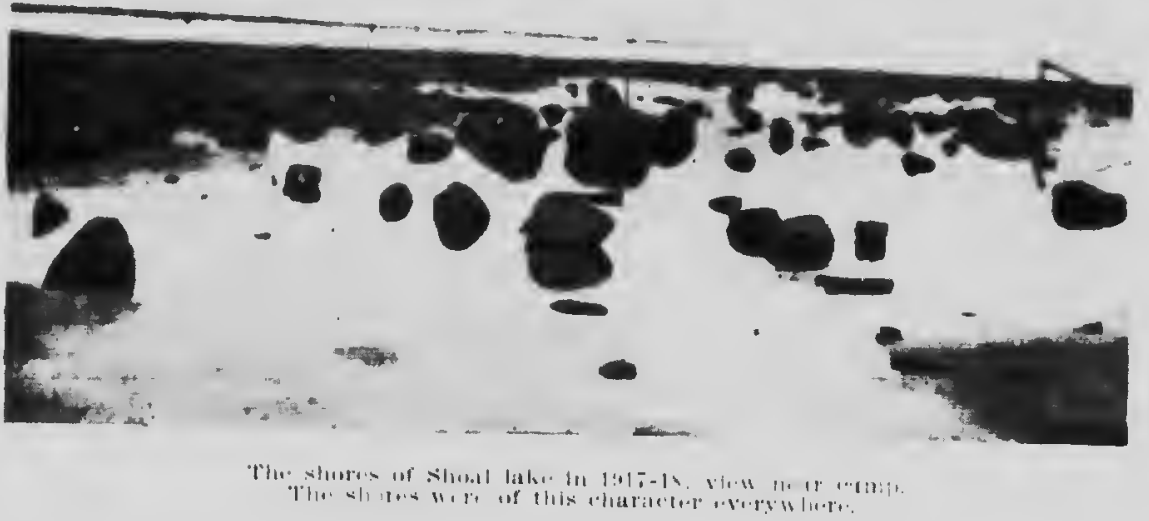

able size had been rc!lcd cver and over on the mud shores by a particularly vicious twister. The squalls do not last long but they try tent material and pegs. The steadier wind storms are violent and sustained and during our stay several of them tested the texture of our canvas and raised anxiety for our specimens and effects. I would advise all future campers to select sheltered spots for their quarters.

In the fall the writer spent from September 17 to 26 in the same neighbourhood to obtain an idea of the autumnal conditions and to sill some of the gaps of the spring work. It was after the first frosts and while the days were warm and pleasant, the nights verged on freezing.

We were disappointed in not finding any great breeding ground for water birds; a few ducks still remained in spite of the altered conditions of the the lake and the ducks and geese, af.er being ccnfined to the narrow strip of open water between the shore and the main ice field, had repaired to mid-lake where they could be occasionally seen and even reccgnized bu: seldom collected. He found the land slightly if any wetter than it had been the previous fall, and where wc had wad:d thigh-dep in the spring was dry and mrowing hay. April and May were very $d_{r y}$, the restriction of marshy areas increasid ance. nn: heavy rains in July failed to replenish them even temporarily. Conscquently, the ducks and water birds that remained in 1917 deserted the vicinity and viry few bred in 1918

Mr. Young worked all the adjoining country in the neighbourhood of the $W$ ard homestead as far as it was possible on foot and made several 


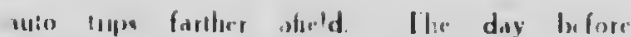
l.e left lir reported a hravy froul. In the courar of this senaents work lee abtaned persentat notes on

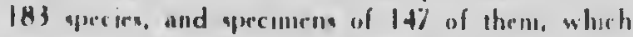
added to the previesus year's ohervalions and col. lectirna, form a sufficient bass for a farly complete

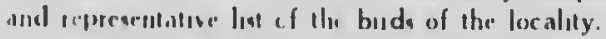

Some frw yeecies are herell included upen cir. cumptamal rondine and until confirmolory npe. cimene ste secured nuat he looked upon as hyposlse lieal. I lowever, the evidence upon whicls they are based is fully geven and the reader call form his own ivdgment a to there value, bearumg in nund, lowsever, that no record is alsolutely unissitilable unel serecumres are aceured and eximined by compeltent autherity:

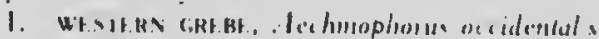

Theugh reported hy all previous olserervers as rewarkably common we silw none at any vielt. The Wiard brothers say that iliey used to breed in such numbers on the marshes that a conoc could scarcely pass between their nests, and Seton reports :!: eprecies as all abundant breceder and notes that "its shrill metallic a m a could he meard f.om the nutal a d d . and nigho". He further observes "it is the casternmecs: breeding plice of the species. Most hide prete. cut towarda the linit; but here, it the northerastern cormer of in limut, this bird has a sort of metropolis". Wuth the loweung of tie water this is all past.

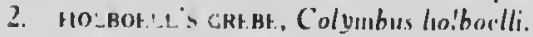

Reported l:y Ciunn "in fair numbers" and by the W'ard brolleres as "never very common". Two seen by Young. May 25, 1918, ars' dll we can report.

3. *HORNED GREH., Colymbus aurilus.

Both Arnold and Raine report it nesting in 1894. One only was noted in 1917, on Jutre $t$. In 1918. Young found it rather common, noting it almost dasly througl May and from the end of July :n S.pi. 2.

4. Fit d-Bil.teld grebf., Podilymbus padicips.

Siton reports it common and evidently breeding. In 1917, we noted hut three in September on a small pond, but in 1918 Young observed individuals. inostly singles. April 25 to May 18. and the latter half of Auqust to the middle of Seplemuber.

3. FCOMnon LOON. Cavia immer.

The Ward brothers siny that it used to breed though they never found its nest. On both visits we aw single individuals almost daily. They were usually observed flying over and seldom showed any inclination to stop on the lake.

6. Iонy GLLL. Pagoplila alba.

I. Mr. Darby' taxidermy establishment in Winnipee, I exam:ned on May 15, 1917, a mounted specimen of this species which I was informed was laken at Wocdlards, Man., on Dec, 27. 1915, a station on the Canadian Northern Railway just south of Slooal l.ake, and hence withon the seope of this

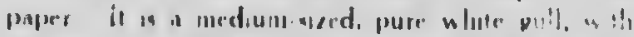
foce and forehead flecked unevertly witls liglit amoky riay. with remains of terminal tal band, dark spots

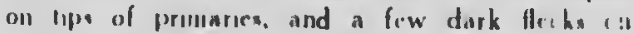
tertiarien, bend of wilk. and lenerer coscris

7. ItH RRING, GLLL. I.arhis argenlalus.

Chapman reporta hading a few Herreng or Coli. fornia Culls Inesting on P'elican Jaland and states that they were wely troublesome to other bilds, destroying numbere of "J'eril's egps and ruent those of the Pelican. Iarge gull, of the flerring Cull iype were seren by un on every vist but were very sliy and all we malloged to lake were Kang-bills. Young tells of a llerung Cull carrying off a Horned Coretir lie had shot and was wading out to retrieve, lifting it bedily by the nape of the neck and iaking it out to unid-loke where, jouned is another. the two poosed

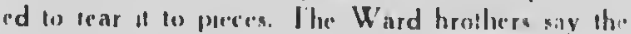
species bred on one of the rocky ialands .19 lite ax 1916, bu: an no bosts were avalable were unt.'.J. to sy whether they continue in do so ur not.

The "precihe status of the larger qulla of the pro. tilece los: not been well determined. Sprecimens of both migranta and breeders wre necessary from varisus localities. The Jerring Cull and the Californin Ciull, I.arus californicus, are so sinular is 10 he deffereniated wilh diffeculty. When juvenile. prebably careful siec camparison berwern simular ages and sexes is the only guide. When adult, prob. ahly the bes: criteria is the colour of the legs and feet: in argenlulus these are Alesh coloured whilst in culifornicus they are said to be light greenah

8. * RING-BILLFD GLLL. Laris delamarani.

Raine reported the surcies breeding on the islands in 1894. We saw a fen in the spring of 1917, but were not always able to separate them with certrinty from the Herring Cull as the ringed bills are cnlv safe criteria when perfectly adult and mon: of the large gul!s seen on the lake showed various Iraces of juvenility. Young recognized the species with reviainty only during the latter part of July. August. a 'd September. Four birds were taken and all are juveniles. They probably do not now nest on the la. e.

9. *Franklin's gull, Larm framplini.

In 1917, common on our first arrival May 17, but became scarcer towaids the latter pal: of our slay, to June 14. According to Young, il was pres. ent on lis arrival on 11:4 lake on April 24, reached a maximum on May 7 , and then gradually b came reduced in numbers to June 7 . It returned on July $I$ and remained until Aug. 27, after which no more were seen. Very large flocks were noted Aug. 8 1o 10. Chapman notes it as breeding, but there is no indication that it nests on the lake now that the inarshes are gone. 


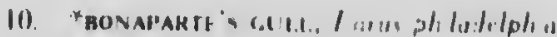
Not ideutified by us in 1917 thoush a Anek of bird noted at a diatance. Sipt. 22, were probably of thas species, as Franklin's Coull serims to Irave before thes date. In 1918, Youns snw fruen on May 25. taking ppecimens in verification. They apprared axain in mone numbers on Aug. 16 and irnalued without mueh dininution up to :'ie date of his leaving, ()e1. 2. Though Seton (Aluk, 1886, p. 147) cites Gunn as the authonty for its breding on Slussl I.ake and repeats the statement in subse.

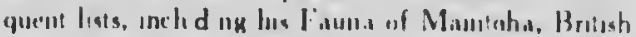
Association Itandhook, 1909. I cannol but irgird it ws mialake, and thunk tha: l'ranthon's Cull has ber'll the basis of these records. The nearest well autherutseated records of the bureduse of this bird is on th. lower Mackenair. The more or Irsu cornmen eceurrener of nonbrecding Bonaparte's Ciull III eumouer dates, as far east as the Ailantic coast. has prohahly been to hlame for many confuson: of hreeding records hetween these simtlar hirds.

11. Caspan tiuv, Siermal capia.

On the gravelly ialands where the Common Tern ured to nest in inumense numbers the $W$ ard brothers t.ll us that there wese ceconional sets of exgs that were in much liarger than the rest as to altraet im. mediate attention. The purents of these seemed to the mo in lee exactly simular to the other tern flying about but considerably larger. Though lhey rewardid them at the tim." as only monsiro:tles thert can be but little question but that these were Caspian Tern. The numerseal ratio these epes bore to hese" of the Conmion Tein was about five to a thousand 12. *. t.R's It.kv, Mtema forkir.

Siete. that while he did not note the specics, M!i!ler ( nrs., found it common or. May 1. 1887. Amold ind Raine report colonies of hundreds of uests, but it is suggestive that they make no merion of the Common Tern. In 1917, we found Forster's "l'erl in company with the Conımon Tern but gencrally scarce. In 1918. Young observed it from th. 8il, to the end of May, but mucl, more common durang the last week. He has one hypothetical record for iso individuals, namely Aug. 21. The

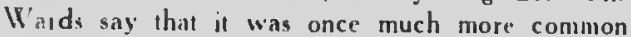
than now and that it used to nest singly on the musk-rat heuses in the marsh and not on the grabclly islets with the Cimmon Tern.

13. "comson TtkN, Sicrna hirundo.

The Ward brothers tell us that when the water was high the Common Tron nested in immense numbers on the gravelly islets. On one such islet of about three acres, they onc: estimated one thousand nests. In some places the foot eould not be put down withou' treading on eggs. This statement is largely confir, ed by Scton. Such descriptions, however, do not represent the species at Shoal Laake now and there is no indicatson of any nestins there. I he vereses wan occanoually enmmon dunng our sprong vist in 1917. In 1918, Young found the m more or lese commen durmo the latter half of May and noted " few individuals occasoually through Junce, July and August and as late as Seput. 16. when a flock of thirty was acen. Ihe Common l'ern ean be sparated from I'orster's in life by the

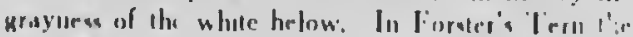
under parts look a dacelinw. pur wlule in the sun. " charactir that is obvious wlies both species are in wew tengether and, after a litule experience, of value when thy are seell separately.

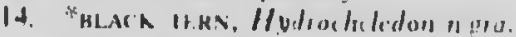

A common hreeding species unsting in the fow wet spots remaining back from the lake. Nune were seen in September of 1917. Young reports heavy mugtistions Aug. I to 21, and the lar. sren, Sippt. 3.

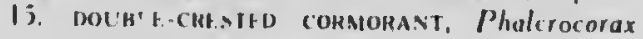
aurifus.

Sald by Gunn. Silus, and the W'and hrothers to lase bern " common hiceder "ill the islands. hu" now, escept for occasional stragglers and during migrations, they have deserted the lake. None were seen by us in 1917, but Young repous flocks of five In sixty in late April and carly May with straggling singles on May 23 and Aug. 29. All seen were Hying over, mestly from cist to west. towards l.ake Manitoba. Prchab!y the: growing athalinits of the lake has destroyed the fish and forecd them to seck other ferding srourds.

16. WIIIt. Phlacas, Pelecunes erylurorhynchus.

sald by the $W$ asd brothers to have been a very common brecder on the islands during ligh water, and Raine speaks of an "Island white with them" in 1894. Seton tells of seing a flock of thirty-five and finding a score of deserted nests, "the eggs strewn about, in some eases evidently sucked. I suppose by Herring Culls". Wir are told that their eqgs used to be reuularly gathered by Indians and others. In one case a boat-load were boiled and fed to the hens. At present or.ly a few sinall focks appear in the spring, and oceasional sunmer visitors. Young reports thirty on May 6, which were all wre saw.

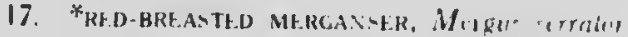

Young found one dead on the beach near the Narrows in the spring of 1918. This is our enly definite record of the sprecies. Though the $W$ ard trothers do not distinguish between the iwo big saw-bills. they repost them common in spring but do not think they breed locally.

18. *llooded MFrGansek, Laphodyles chelillatir.

Young reports this species in early May, the middle of June, late July and the last of August. The Wards state that it breeds in the neighbourhrod and that young in flapper stage are often 
seen in small pools and standing in ditch water along the railroad tracks, and that it is one of the earliest of ducks to mature.

19. * mallard, Anas plalyrhynchos.

One of the commonest ducks though being rapidly reduced as a brceder by the progressive restriction of suitablc marshes.

20. "BlaCk duck, Anas rubripes.

The Ward brothers seem to know this species and describe it as a ra fall migrant. We are in riceipt of a specimen labelled Winnipeg. Man. (W. R. Hine) which we are informed by its donor, Mi. Seton, was taken at Shoal Lake. The date is not reccrded.

21. *G.10WELL, Chaulelasnius strcpert:5.

Raine found nests in 1894 and Seton noted them on Pelican Island on July 6, 1901. Wards say it is, or was, an uncommon but regular breed.r. Specimens were taken on May 15 and 19, 1917. and Young reports a few individuals during May, 1918.

\section{Baldpate, Marcca aniericana.}

Raine found nests in 1894 and Chapman in 1901, and the $W$ ard brothers say it is onc of the scarcest of the ducks and growing more so. Young reports seeing individuals at the end of April and in the beginning of May, 1918.

23. *GREen-WINGed TEAL, Neltion corolinenje.

A common breeder and still lingering in some numbers, sceming to require 'ess extensive marshes than many other species of duck.

24. *BLUE-WINCED TEAL, Qucrquedula discors.

A common breeder similar to the green-winged but seen considerably later in the fall.

25. CINNAMON TEAL, Querquedula cyanoptera.

Se:on (Aule. 1886, p. 328) quotes R. H. Hunter as having taken a specimen at Oak Pount, on the adjacent Lake Manitoba shore. This is near enough to the locality under discussion for mention though the lack of recent records for the species and apparent absence of specinens rend $x$ i a lit? unsatisfaclory.

26. Shoveller, Spaitula clypeala.

A common breeder in 1917. Said by the $W$ ards to be the only duck that is showing an increase, and they d:scribe, during the past three years, vast focks of a lliousand or more in eclipse, remaining until the fall plumage is assumed when they depart for the south. However this may have been just previous io 1917, we have seen nothing like it in the last Iwo years. They are present throughout the epring. but Sept. 17-26 may have been too late for such aggregations in 1917. Young was present all the summer of 1918 and only noted occasional birds through April and May. so it is prohable tha! the above increase was only momentary and was checked by the continued ecological changes in the Iccality.

\section{7. * Pintali, Dafila acula.}

$W$ as a common breeder. Said by the $W$ ard brothers to mature earlier than any other species of duck exccpt the Hooded Merganser. More Pintails were seen during the spring of 1917 than any other kind of duck. In 1918, Young found them very common in early May, gradually reducing in numbers after the middle of the month, scarce in midsummer, which herc gives no cover for eclipse conditions. The last noted were fifty on Sept. 16. 28. WOod Duck, $A$ ix sponsa.

The Ward brothers give circumstantial accounts of the occurrence of two Wood Ducks at different times. One male taken in 1899 or 1900 was identified as such by a Mr. Robt. Holland, who was familiar with them in Ontario, and the other from memory of that specimen. Whilst these records are not unimpeachable, taking into consideration the s'riking charactcrs of the birds ard the qualifications of our informants, I accept them with but slight rcservations.

29. REDHEAD, Marila anericana.

Arnold found ncsts in 1894 and the Wards say that it used to breed. We saw only occasional specimens during spring and fall.

30. *Canias-Back, Marila vallisneria.

Said by the $W$ ards to have been a common brecder in the past. A female was taken on June 6. 1917, but it proved to be a non-breeder. We have only seen occasional individuals in spring and carly summer.

31. * Lesser scaup, Marila affinis.

A considerable number of Scaups were noted during both spring and fall. All taken proved to be the Lesser Scaup, though undoubtedly the Greater Scaup also occurs. The Wards know of but one nest being taken, that one being amongst the gulls on an island.

32. "RINC-NECKE.D DUCK, Marila collaris

Nothing like as common as the Scaups. A few were observed in the spring of 1917 and specimens taken in the following fall. It was not observed by Young in 1918. The Wards know it under the name of "Buck-eyc", and say that it occasionally eccurs in small focks but do not know of its breeding.

33. AMERICAN GOLDENEYE, Clangula clangula.

A flock of six were seen between May 17 and 23. and a pair hung about until the first week of June in 1917. Young noted one on July II, 1918. All adult males observed were of this species. We have no record of its breeding.

34. Barrow's COLOENEYE, Clangula islandir=. Seton ( 1 in, 1896, r. 329), cites R. H. Hunter as aulhority for the capture of a drake on Shoal 
Lake in the spring of 1880 . It is a long way from normal range of the species and should be authenticated by specimens for unreserved acceptance. The $W$ ards are unaequainted with the species.

35. BUFFLEHEAD, Charilonella albeola.

Said by the Wards to have been a common migrant, but not known to breed. Seen on May 19. 1917, and a few in late April and early May in 1918.

36. HaRlequin DUCK, Histronicus histronicus.

Frank Ward tells us that in the spring of 1898 he shot three brilliantly coloured little ducks that he was unfamiliar with. At the time he thought they might be Wood Ducks, but upon seeing that species later realized the mistake. He identified t'ans as similar to coloured pictures of the Harlequin Duck in Reed's Bird Guide. Taking everything into consideration I am inclined to accept this record with but few mental reservations. EIDER, $S_{p}$ ?

The Wards tell of a large duck of unknown species, with greatly swollen bill, having been taken 1. Mr. Samuel Martin, of Winnipeg, about 1900. Plumage descriptioris seem to suggest a female, either Eider or Scoter. If Eiders, ever occur they must be accidental stragglers and except for the above uncertain record they are 'Inknown on the lake.

WHITE-WINGED SCOTER, Oidemia deglandi. Seton found nest and eggs on Pelican Island on July 6, 1901. This is the only Scoter known to the Ward brothers, who say that when the lake was fished many were taken in the nets. We saw small flocks almost daily in the spring of 1917, and Young reports occasional individuals throughout the season until Aug. 10.

38. RUDDY DUCK, Erismalura jamaicensis.

Reported by Seton, 1886, on the authority Hine to breed at Shoal Lake. Said by the Wards to have bred very commonly but not often taken. It has practically disappeared from the marsh since the drying of the marshes. Young noted one individual on May 29, 1918.

39. SNOW COOSE, Chen hyperboreus.

Single individuals seen on May 25 and 28, in 1917, a large flock on April 30, a smaller one on May 25, and two individuals on Oct. 2, in 1918. The resideuts are enthusiastic over the "Wavie" shooting. I take it for granted that all are Lesser Snow Geese, C. h. hyperboreus. It is locally called Greater, but apparently in contrast with Ross' Coose, which sems to be as well known as the "Lesser Wavie".

40. BLUE COOSE, Chen caerulescens.

One was seen on May 29, !917, in company with a Snow Goose and watched for some time in suud he!d-glass range. Th. black and white head and neck nuade identuscation positive. Young noted a flock of one hundred on April 30, 1917. and a few more individuals on Oct. $I$ and 2. The Ward brothers say that in most flocks of Snow Ceese a few of this coloration occur, but no! many are taken.

41. Ross' Coose, Chen rossi.

The Wards differentiated between the Creater and Lesser Snow Geese, but upon questioning it appeared that the latter were little larger than Mallards. There can be little doubt but that this is the species referred to. They are only occasionally scen on the lake, but numbers have been brought into Winnip" : narket.

42. WHITE-, iNTED coose, Anser alb frons.

May 26, 1917, one pitched on an isolated rock off the shore within sight of camp, from whence we watched it with glasses for a considerable time. The general brown colouration, white frontal patch and pink bill and feet were plainly visible and there can be no doubt as to the identification. The $W$ ard brothers say it is scarce within their experience and know of but six individuals being taken on the lake.

43. * Canada goose, Branla canadensis.

Besides seeing the species during spring and fall in 1917. Young noted individuals as late as June 4 and as early as Aug. 10 in the following season. Arnold reports finding a nest on an islard in 1894 and doubtless the present breeding ground is uot far andy. Two captive birds seen were evidently $B$. c. hulchinsi. One specimen obtained on April 30, 1918, is $B$. c. canadensis. The $W$ ards and others say that the two large forms of Canada Goose can easily be told apart in life, having different voices and the flocks keeping more or less separate. The living birds of the small form do not make good decoys for the larger. They also upon their own initiative tell of occasional very small Canadas, scarcely larger than Mallards, and with voices like a hard cack-cack-cack. They are very scarce and there can be little doubt but that they are stragglers of the Cackling Coose, $B$. c. minima. 44. BRANT, Branla berniola.

Reported by Seton ( $A$ uk, 1886, p. 329), on authority of R. H. Hunter, to have been killed at Shoal Lake. As Geo. Atkinson records in his Rare Birds of Manitoba (Trans. No. 65, Hist. and Sci. Soc. Man, 1904), a specimen in his possession from Oak Lake, killed the spring of 1889, the secord is not an isolated one for the province.

45. WhistLING SWAN, Olor columbianus.

The Ward brothers iell us that $S$ wans are still common migrants, especially in the fall and do not seem to be decreasing to any marked degree. We saw none in 1917, but in 1918 Young noted thirty on April 30, and six on May 6. 
46. TRUMPETER SWAN, Olor buccinalor.

The $W$ ard brothers have abserved Swans of two different sizes. One shot in 1904 weighed thirtyin'o pounds and was so large that Frank Ward, a large man, could not close his hand about the neck behind the head. Mr. W ard, Sr., says that swans nested on the lake in 1893-94 and that he watched the old ene with cygnets one day for hours. This can only refer to the Trumpeter Swan and is strong circumstantial evidence of its occurrence. Our informants also tell us that the big swans are not as wary as the small ones, do not keep as consistently in the centre of the open lake, and are more easily taken. The voice is also quite different from that of the smaller species, being either a single "Whoop-Whoop" or a louder, clearer, and less shiil "Coo-coo-_." that can be plainly heard for miles. Frank Ward tells of a wounded one uttering a long drawn note of such extreme mournfulness that it moved him deeply, thus substantiating, in a measure, the fabled song of the dying swan. These trumpeters do not come with the large flocks of Whistlers, but usually as individuals accompanied by one or two dark cygnets. Two have been seen as late as the early spring of 1917.

\section{( To bo confinued.)}

\section{THE ORCHIDS OF HATLFY, STANSTEAD COUNTY. QUEBE.C.}

\section{By H. Mousley.}

In that interesting book. "How to Know the Ferns", Mrs. Theodora Parsons recounts how a friend'y rivalry used to exist amongst fern students as to who could claim the greatest number of species for a given area. Possibly if such a rivalry exists amongst students of the orchid family, I might take a prominent place, for I can lay claim to having found seventeen species and one variely of orchids (or jus! one-quarter of all those known to occur in Fictern North America) within a radius of one mile of my residence, and I am beginning to wonder whether Hatley is nol an "F.l Dorado" for these lovely flowers, the same as Dorset and Pittsford (both in the State of Vermont) are for ferns. On a two hours' walk in the former place thirty-three species and four varieties of ferns have been found, but then it must be remembered that the party finding them had mad: the study of ferns a spiciality. whereas I do not lay any claims to being considered a specialist ill orchids or evell a botanist. Still from childhcod I have always had an innate love of line beautiful, and it has been wl:ilst pursuing my favourit. tudy of ornithology, that 1 have made a side. line. so to speak. of botaly, having collected ard named sone two hundred or . wre local species of wi'd flowers, at odd moments whell from sont" cause or another birds were scarce. Possibly 1 ow my suecess with the orchids almost entirely to the warblirs, for in making a special study of this family of birds, I generally seem to have been most fortunate in securing $\mathrm{my}$ rarest finds, the following up of a Cape May W'arbler (Dendroica ligritu) for instance giving me my fiss sight of that exquisite. little orclid. Culvpsa bulbosa.

Hatley is a pretty little village lying at an elevation of 1,000 feet above the sea level, the country all round being of an undulating character witl plenty of small streams, many of which eventually find their way into I ake Massawippi, a fine sheet of water abcut nine miles long, lying on the western side of the village. Betwer this lake and the village there stretches a long belt of lew.lying woods composed largely of spruce, fir and cedar, with hrmlock. maple, birch, becch, ash and other deciduous trees intermixed. It is in these wocds principally io the north.west of the village that most of my records have been made, although there is a famous bog to the north-cast, where several species are to be found growing in profusion including Arcthusa bulbosa.

During most of my eiglıt years' residence here (1911-1918) I have resided about one and a half miles to the se $h$ of the village, but in May, 1917. I made a temporary change and occupied a house about a mile or rather more to the north of th" village until October, 1918. Previous to making this change I had only observed six species of orchids to the south of the village, so that $\mathrm{my}$ change of residence is responsible for an additional twelve, the ground being of a more swampy nature and better suited to the requirements of orchids, although I do not wish it to be understeod that a systematic worker could not find any of these Iwelve additional ones to the south or east of the village, for indeed I myself have already done so during the present year (1918): nevertheless I think the locilities indicated will be fourd to be the most productive, as the following annotated list (take't in the order given in Gray. Manual of Botany, Seventh Edition) clearly shows:

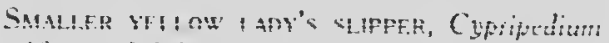
paniflorum Salisbury. My first acquaintance with this fragrant flower was on June 22.1917, when 1 


\title{
THE OTTAWA NATURALIST
}

\section{THE BIRDS OF SHOAL I.AKE, MANITOBA.}

\author{
By P. A. Talerner.
}

\section{(Continued from page 144)}

46. *american bittern, Botaurus lentignosus. In 1901, Seton found it abundant and breeding. He says: "A conspicuous feature of the landscapehard at work night and day pumping out the bog". We found it in no such numbers. May 19 10 21, 1917, one was heard each night in a marshy spot behind camp. The next day one was taken but we did not hear t':ie species thereafter. This bird was a male with the skin of the throat greatly thickened with a tough gelatinous lissue inside that I have met with a number of times before in spring males of this species, but have never seen referred 10 in print nor found ornithologists generally familiar with it. The tissue is very much like that behind the throat puffs of the courting Prairic Chicken and, judging from the dried specimens of breeding spring Pectoral Sandpipers in our collection, probably similar to conditions found in the inflatable sac of that species. As the Bittern inflates its throat while courting or booming it is likely that this deposit is of similar origin in each of these species. It lines the inside of the skin perhaps one-eighth of an inch thick and is soft and rubbery, firmly attached to the skin, and sliding away under the knife in a manner that makes its removal very difficult. In 1918. Young saw occasional birds in May, June and August.

47. Great blue heron, Ardea herodias.

The $\mathrm{W}$ ard brothers say that this species was rare on the lakes even in time of high water and extensive marsh They rarely observed over one or two each year. In 1918, Young repo:ts seeing two birds on July 10 at the Narrows.

48. BLACK-CROWNED NIGHT HERNN, Nycticorax nycticorax.

Reported by Chapman as breeding on the ground in reeds two to three inches above water, the record is accompanied by photographs of nests in "Camps and Cruises". It is said by the Ward brothers to have nested in large colonies on the floating debris where the drift of the lake came in at the edge of the marshes. Only a few migrants have been seen of late years. Seton describes a night herony where "scores, probably hundreds of nests, were in the tall quill-reeds; but none at all to the trees". He quotes a resident farmer, C. H. ileacham, as authority for the statement that three years previous (to 1901) there were but twenty pairs present, but remarks that their rapid increase was marvelous, stating, "No doubl this is one of the species whose number fuctuate with the rise and fall of the lake". thus forcasting their present disappearance again. 49. WhOOPINu CRANE, Grus americana.

We were informen by the $W$ ard brothers that Whooping Cranes used to breed and be fairly plentiful. About 1901 they saw thirty birds logether. They have grown much scarcer of late years, but still a few are seen each season. In 1916, three were seen by Frank Ward, and even in 1917, about a week $b$.fore my return visit, two passed immediately over him flying very low.

50. SAND-HILI. CRANE, Grus mexicana or canadesis.

In 1917, we saw no cranes but a nearby farmer had heard them a few days previous to our questioning. We looked for them but found their old haunts dried up and encroached upon by settlers. The Ward brothers say that, until very recently a few still bred on nearby musk gs and in lale summer and early autumn they visit the grain fields in large flocks, but are $d$ creasing. A few days previous to my return visit in the autumn, William Ward saw severa!, but regarded this as a late date. In 1918, a number were observed shortly befcre Young's arrival, and he noted one April 25. Small flocks of from three to eight were seen later from August 15 to Sept. 6, usually high in the air. The Ward brolhers think they recognized two sizes in the cranes commonly sern, which wonld indicate that both the Sandhill and little Brown Crane occur; in which case the former would likely be the bre:ding form, and the latter a migrant. 


\section{1. *Sora Rall. Porzana carolina.}

During the spring visit of 1917 there were innumerable suitable places for rails and their voices were heard a number of times, but we saw only a single bird on May 30. The $\mathbf{K}$ ard brothers are, quite excusably, uncertain in their identifications of the various species and ''umages of the rails. They claim to have found nests of three species; and speak of a small black one which is likely the young of the Virginia. In 1918. Young reports Soras rather scarce in spring but becoming very common in August. On Aug. 2 he counted over fifty in one small wet marsh. After that they gradually reduced in number, and the last one seen was on Sipt. 20 .

\section{YelLow RAlL, Coturnicops noveboracensis.}

Though this little rail should be common, it is such an accomplished skulker that we saw none. The $W$ ard brothers tell of nests of very small rail eqgs, and during my autumn stay in 1917. Frank Ward, while raking hay, uncovered and forced into flight some small rails with large amounts of white on the wing. He was unable to capture any at the time, and though I later watched haying operations in adjoining localities closely, no more were discovered. In the same vicinity while hiding in the grass near a small pond, I heard a repeated bird voice suggesting a rail close by, but was unable to flush the author. I have little doubt but that they were from Yellow Rails but am unable to substantiate my conclusions. Through the summer and autumn of 1918, Mr. Young watched haying operations closely but was unable to dctect any Yellow Rails. 53. *american coot, Fulica anicricana.

Chapman, in his "Camp and Cruists", gives photographs of a Coot's nest taken in 1901. Not seen by us in 1917, but in 1918. Young observed small numbers to May 21 and flocks of 100 to 150 the last of September. Said by Seton and the Ward brothers to have been a very common breeder when the water was high and even up to three years ago, in favorable localities, a few still ncsted.

54. *Nortiern phalarope, Lobipes lobalus.

A few seen in 1917 among the groups of Wilson's Phal ropes between May 23 and 29, perhaps iwelve in all. In the autumn three were seen on Sept. 22 and again on the 24. Specinens were taken during both seasons. Regardea by Ward brothers as rather scarce. In 1918, Young noted occasional flocks, beginning with 20 on May 29, culminating in 100 on June 1 , and a few remaining until June 12. In autumn he observed small groups from Aug. 20 to the end of the month with a straggling flock on Sept. 21.

55. "Wilson's PHAlarope, Stcganopus tricolor. During the 1917 spring visit the commonest and most generally distributed wader. Nearly every little slough had a pair or little group, usually females gracefully swimming about, and a nest of fresh eggs wa, collected on June 6 . Young tells of a flight song he saw executed by a female in the rresence of her (prospective?) mate. During it she distended her throat in the same manner as the Pectoral Sandpiper is reported to do. The $W$ ard brothers state that they have seen this courtship flight a number of times. At another time a Phalarope was whirligiging in its characteristic manner in shallow water: upon examination the bottom below it was found to be scratched in semicircles as if with the feet. The Phalarope seem to be entirely surface feeding birds, never dipping down into the water for food. Fividently this graceful spinning is a method of stirring up the water and bringing small particles of food to the surface within reach of the delicate, rapier-like bill. The usual note of the species is a miniature quack, like that of a domestic duck but less loud. From this they are locally called "Grunters". None were seen during the return visit in the autumn of the year. Owing to the progressive drying of the marshes. Wilson's Phalarope was not quite as common in 1918, but Young rccords a few almost daily from May 7 to Aug. 20 when the specirs disappeared. 56. *wilson's sNipe, Gallinago delicaia.

Quite common in 1917 and, though no nests were found, evidently brceding. The sound of its aerial dive and love-making flight could be heard each evcning, and occasionally throughout the day. A few were still present during the autumn visit in September. In 1918, Young found it rather less numerous from May to August, but very common in September, and to the time of his leaving on Oct. 2.

57. *Dowitcher, Macrorhamiphus griscus.

On May 18, 1917, one was dropped from a large flock as it passed the tent and another was taken on May 30. In 1918, Young saw small bunches on Miay 22, 25 and 28, and Aug. 9. Of six adult spring specimens but one can be particularly referred by bill size to $M$. g. griseus and two to $M$. g. scolopaceus, the remainder falling into the overlapping meastirements of the iwo forms as given by Howe, (Auk, 1901, pp. 157-162). In coloration the birds scem to agree most closely from descriptions with scolopacins but without direct com parison with birds of easiern origin I would hardly like to make a definite diterinination; on geographical grounds they shcu'd be referred to $M . g$. scolopaceus.

58. * StiL' SANDPIPER, Aficrupulmu h:manlopus.

In 1917, a flock of twelve were noted wading "kriee deep" in the shallows of the Narrows on May 
25 , and on May 28 twenty-five more were observed in the same place. In 1918. Young observed eight on May 25 and 28. They returned again on Aug. 26, and from four to six were seen to the end of the monih. The Wards regard them as common migran:s.

59. * pectoral sandptPer, Pisobia maculala.

On May 25, 1917, a small flock of eleven waders that we took to be of this species were seen. On June 2 a single individual was taken. Young did not see the species in the spring of 1918, but on Aug. 24 ten birds appeared and he noted them almost daily, in numbers furtuating between four and fifty, to the end of September. Only one of these, taken Aug. 27, is adult.

60. * White-rUMPEd SANDPtPER, Pisobia fuscicollis.

In 1917 a single individual was seen on May 29 in company with a flock of Least Sandpipers, but it was very common on June 2 with large mixed flocks of Least and Semipalmated Sandpipers and Plover. In 1918, Young observed them almost daily from May 22 to June 12, and a later group of four on June 20. On Aug. 7 ten re?urned and remained in approximately constant numbers until Sept. 12.

61. *Baird's sandPIPer, Pisobia bairdi.

Not recognized in 1917. Amongst the small waders collected by Young in 1918 are individuals taken on Aug. 8 and 9 fron companies of Whiterumped Sandpipers.

62. *least SANDPIPER, Pisobia minuli!la.

In 1917, very common until June 6 , when it departed with the majority of the other waders. During the September visit, I saw a number of small sandpipers with Semipalmated Sandpipers and Plover that I took to be Leasts, though the presence of more important material near by prevented shooting them for absolute verification. In 1918. Young reports the first Least Sandpiper on May I6, becoming common on the $28 \mathrm{th}$, and remaining so until June 12. Individuals were seen June 20 and July 27. but the species did not return until Aug. 22, remaining until Sept. 7.

63. * RED-BaCked SandPIPER, Pelidna alpina.

Common in the spring of 1917. First noted on May 25. Most abundant on the 28th; they di:appeared with most of the other migrant waders on June 5. In 1918, ubserved from May 22 to June $!$ in limited numbers; not noted in the autumn of either years.

64. *semiPalmated SANDPtPER, Ercunetes pussillus.

Is 1917. we did not note this species definitely amongst the flocks of mixed small sandpipers until May 25 when they were selected from a bunch of
Leasts and collected. On June 2 the flocks were composed almost entirely of this species and three solitary individuals were seen after June 5 . A few were seen and collected during the autumn visit Sept. 22. In 1018, Young reported them between May 19 and 29, and again in the autumn from Aug. 23 to Sept. 10.

65. *Sanderlunc, Calidris leucophaea.

In 1917, common in the mixed flocks of small waders from May 28 to June 5 when most of the migrant shore birds left. In the fall several were seen on Sept. 24. In 1918, seen by Young from May 19 to June 12 and again from Aug. 8 to 31 .

66. MARBLED CODwIT, Limosa fedoa.

Though the Wards recognize two Codwits occurring at Shoal Lake, we were unable to positively identify the Marbled, though several flocks observed the day of our arrival, in 1917, we tentatively ascribed to this species. The Wards do not know of either species breeding.

67. *hudsonian codwit, Limosa hacmastica.

One of the surprises of the 1117 trip $w$ as the re. discovery of this fast disappear $g$ species. On May 18. Young took one male fro. a flock of five and the day after I saw a bird tt I I was satisfied was of the same species. In 19ij, Young saw flocks of 12 and 15, on May 21 and 25, and a single bird on the 29th. On July 31, five more were noted passing over towards Lake Manitoba. Of the specimens taken, two females have considerably more white and grayish feather edgings below than the males and a third shows this sexual (?) character less distinctly. The Ward brothers say that the Hudsonian is the commoner of the two Codwits and that it is more easily approached and shot. The fac' is they call this the "Foolish Codwit" and say it can be repeatedly approached after having been fired at. This is quite similar to an experience I had with a bird of the same species at Point Pelee, Ont., in 1915, when I stalked and secured a specimen after having once missed it. In seeking for a cause for the rapid decrease of the species this unwariness should be considered as a factor. It may be that similar habits will also explain the unexpected disappearance of other species. (See anica. Trumpeter Swan.)

63. *Greater Yellow-LeGs, Tolanus melanolcucus.

But single birds identified May 27 and 30 in 1917. In 1918, Young found it present in small numbers in a ratio of about one to ten, as compared with the Lesser Yellow Legs, from April 24 to May 15, leaving about two weeks before the latter. In the autumn but casual singles were seen between Aug. 21 and Sept. 12. Said to have been the commoner of the two Yellow-legs when the lake 
was high but now much less numerous and growing scarcer.

69. *Lesser yellow-lecs, Totanus faripes.

In 1917 common from the time of our arrival on May 17 to June 5 when most of the migrant waders left. One was taken Sept. 21 on the shore of a small pond some distance from the lake. In 1918. the species was common from April 25 to May 28, and abundant from May 5 to 15 . In the autumn stray individuals appeared July 13 to 20 , but the bulk did not arrive until Aug. 4, culminating in numbers on the 19:h, and remaining until Sept. 7.

70. * Sol.ITARY SANDPIPER, Helodromas solitarius.

In 1917 but single specimrns occasionally secn during our spring visit and one noted Sept. 17. In 1918 snail numbers were sech refulirly between May 8 and 27, and Aug. 5 and Sept. 18.

71. *Willet, Caloptrophorus semipalmatus.

In 1917 one bird was observed from the train between Winnipeg and Frinview, but the species was not noted on the lake. In 1918, Ycung took single individuals, the only ones noted on lhe lake, on May 29 and Aug. 10. The spring adult of these two is so decidedly grayer than a Sapelos Island, Ga., bird and both agree so perfectly with comparab'e material from Saskatchewin and Alberta, that I have little hesitation in referring them both to the Western Willet, C. s. inornatus.

72. *teland P:over, Bartrmmia lonicicauda.

Said by Seton to have been "somewhat common" in 1901, "but nearer Winnipeg, where the prairics were drier, it became more abundant". Evidently the drying of the prairic has allowed it to increase its range considerably for we found it a very common bird in 1917, and the $W$ ard brothers say it is increasing. One could hardly go five minutes in any direction from camp without coning across one or more pairs, while its long-drawn whistle was one of the most characteristic and beautiful of the prairie sounds. On the ground the Upland Plover has a very un-wader-like appearance looking more like a long-legged grouse chick, but immediately it takes flight the long sweeping wing strokes proclaim its true relationship. It breeds commonly about the lake, but its eggs, surprisingly large for the size of the parent, are very difficult to find. The parents are very solicitous for the safety of their nests and show great ingenuity in diverting the attention of the intruder. It was $n$ " present on my return visit in Seplember. In 1918 it put in an appearance on May 7 and remained common until the middle of A.dgust, the last one being $\operatorname{secn}$ on Aug. 28. Mr. Young informs me that he looked very carcfully for juveniles through the sumaner but withuut success. Adults were in common evidence the entire season but even the mowing-machines of the hay-makers failed to discover young or partially grown individuals. How so large and prominent a bird can be raised to maturity without observation is problematical.

\section{3. *BUFF BREASTED SANDPIPER. Tyngites subruficollis.}

Young met single individuals of this rare species on Aug. 9 and 31, collecting the latter one. The growing scarcity of this species is a matter of some anxiety to those who view with alarm the general decrease in our shore birds.

74. *spottrid SANDPtPER, Actitis maculata.

This unusually common species was unaccountably scarce on the lake shore in 1917 where conditions seened ideal for it. We only saw occasional individuals and some days along the lake shore we would fail to see a single bird. In 1918 the species seemed slightly more numerous but still far from common and the greatest number noted any one day was 8 on Aug. 21. It was not noted in spring until May 18 and the last one was seen on Sept. 21.

75. LONG-BILled CURLEW, Numenius americanus.

In 1917 we saw birds in the distance several times that we took to be Curlew. Young did not observe ii in 1918. The $W$ ard brothers know of but one specics. I include them under this species hypothetically.

\section{6. "BLACK-BELlied Plover, Squatarola squatarola.}

In 1917 seen from May 26 to June 1, and again on Sept. 22 and 24. Said to be more common in autumn than ir spring and to stay very late. In 1918. Young noted small flocks numbering from 3 to 15 on May 22 to June 3. A single individual was scen on June 20 . In the autumn similar numbers were scen from Aug. 8 to Sept. 23.

77. *COLDEN PLOVER, Charadrius dominicus.

In 1917 one seen on May 22 and another on the 26!h. In the autumn one specimen was taken on Sept. 22. In 1918, four and three were noted May 30 a: ! June 4 and 6 and one on Aug. 21 and on Sept. 21.

78. *hllLdeEr, A egialitis vocifera.

Very common and breeding everywhere. One could hardly get out of hearing of its querulous complaining. In the autumn several were seen in 1917 and until Sept. 19, 1918.

\section{9. *semipalmated plover, Aegialitis scripalniala.}

First seen in 1917 on May 19, common on the 28th; none observed after June 5. Present in $191 \mathrm{~J}$ from May 20 to June 12, and from Aug. 1 to 31. with a single straggler Sept. 14.

80. Frirtic Ploier, Aegialitis meloda.

One or two pairs were usually to be seen on the flats raar the Narrows, where they associated with 
flocks of Semipalmated Plover and other small waders. W'ithout doubt they breed though we discovered nu nests. In 1918 the Piping Plover was present in small but constant number: continuously from May 15 to Aug. 30, and a single individual noted on Sept. 7.

81. *turnstone, Arenaria interpres.

Five seen in 1917, May 25 and 30 , and six on June 3; none thereafter. In 1918, the species arrived in large numbers $(500)$ May 28 , gradually reducing to 2 on June 12. In the autumn a tew individuals were noted on Aug. 7 to 27 .

82. * RUfFed Grouse, Bonasa umbellus.

A few Ruffed Grouse still hold out in some of the larger bluffs. Their far carrying drumming was often heard and three specimers taken in 1917. According to Ward brothers, they were once very numerous indeed, but are getting very scarce. They do not seem to have learned the wariness that uur eastern birds find necessary to existence, and still allow themselves to be treed by the dogs or shot on the ground in truly primitive manner. This and the unusual number of Goshawks and Horned Owls that invaded the country in the winter of 1916-17 are probably the causes of the great decrease in numbers. Though the Gray Ruffed Grouse, $B$. u. umbelloides, that inhabits the prairies is not a very well marked or stable race these are quite typical of that form. 1918 did not show much improvement in the Ruffed Grouse situation and no increase was apparent. One specimen taken is slightly more red than those of previous years, but we obtained none of the large red phase that Seton mentions as occurring in Manitoba and of which the Wards seem cognizant.

83. PTARmican, Lagopus (lagopus?)

The Ward brothers say that they know of five Ptarmigan being killed within a few miles of ous camp-always in winter of course. If the Ptarmigan ever occur here they are in all probability Willow Ptarmigan, $L$. logopus.

84. *PRAtRtE CHICKEN, Tympanuchus amcricanus.

The Ward brothers say that this species appeared commonly in the Shoal Lake country some 13 to 15 years ago, though Arnold records nests in 1894 at the south end of the lake and Seton saw one in 1901 . They increased to great numbers, but the last fex. years have died out together with the other grouse both Sharp-tailed and Ruffed. Of this I have more to say under the following species. Throughout the Canadian west the name of this species has been given to the Sharp-tailed Grouse and wherever the term Prairie Chicken is popularly used it is that species that is meant. However, correctly speaking. this is the true Prairie Chicken and has a prior right to the name. Taking into consideration the con- fusion that has arisen between these two species it might be advisable to apply "Prairie Chicken" to either species of Prairie Grouse indiscriminately and revive the equally satisfactory name Pinnated Grouse for this species. About Shoal Lake the true Prairie Chicken is called "Square-tail" or simply "Grouse". Unlike most of its family this species is partially migratory and most of them disappear from the northern sections of their habitat in winter. The Wards tell about a tame Prairie Chicken they had for several years that returned regularly each spring and was as much at home about the place as a dog or a cat and quite able to protect itself against these natural enemies. Once, during migration, it was noted in the outskirts of Winnipeg whtre its tameness attracted interested attention, and a newspaper paragraph, while its identity was substantiated by its lack of a toe.

We saw very few scattered individuals during the spring visit of 1917 , though their dull booming while love-making could be heard at all hours of the day. This sound has a peculiar intensity and wonderful carrying power and is as casily heard a mile away as just across a field. The cunstant recccurrence of this sound in our ears, :herifore, was not an indication of large numbers of the species. but of the great extent of the country within auditory range. We probably heard the same individuals again and again. The birds wcre very wild indeed flushing at a great distance from the intruder and fying a mile or more before alighting. In the autumn I found them considerably more cominon probably owing to the successful raising of a $5 \mathrm{cw}$ broods. Contrary to cxpectations. Young fcund the species even less common in 1918 than the previous year. Probably the fall shooting was more than their reduccd numbers could stand. A close season of sume years on this bird seems expedient to bring them back to their normal numbers.

\section{5. * sharp-tailed crouse, Pedioccetes} phasiancllus.

This is the original prairie grouse of the Canadian plains. It has been gradually displaced in southern Manitoba by the true Prairie Chicken or Pinnated Grousc of further south. Though generally called "Prairie Chicken' it has no tille to that name having a perf ctly good and distinctive one of its own as above. About Shoal Lake, we found it even scarcer in 1917, than the real Prairic Chicken which seems now to be the most characteristic game bird of the locality. During the spring visit we saw but two birds and inquiry amongst the farmers elicited reports of but a few more individuals. In the autumn none were seen. In 1918, Young found it still scarcer than the previous year only noting it once at Shoal Lake on Sept. 21, though a flock of 
20 were seen on Sept. 29 at Lake Francis at the south-east end of Lake Manitoba when it seems that the species enjoys better conditions. Though urdoubiedly overshooting has had a powerful infuence in the depletion of the grouse of the prairie provinces it was probably not the whole cause. Throughout the proviners of Manitoha, Alberta and British Columbia we heard practically the same report in 1917. A great abundance of grouse of all kinds followed by sudden disappearance. Coincident with this were unusual numbers of Goshawks and Horned Owls through the late fall and winter of 1916.17 and the failure of the rabbits of all kinds both locally and throughout the north. The connection between all this is obvious. The regularly re-occurring dying of the rabbits through the well known rabbit disease deprived the large raptorial birds of their usual food supply, and they were forced to come into more soulliern sections and turn their attention to the only food to be found there, the grouse, with the result that the latter were practically cleaned out. The story is remarkably consistent wherever we obtained first-hand evidence, and applied as well to the lonely reaches of the Red Deer river valley, the preserved areas of Dominion Parks, where shooters rarely or never penetrated, as to sections adjacent to dense settlement where the sportsmen would be a inost inportant factor. When limited to animal or stcam locomotion the radius of action of the shooter is comparatively emall and in the vast extent of the western provinces there remain large expanses where the birds can live practically undisturbed. By use of the automobile, however, there is little chance of retaining sanctity for any purely natural reservation. However, it cannot be doubted that this parlicular and present low ebb in upland game life is due more to natural causes than to man. Caution inust be used in advocating the destruction of large hawks for it is only a few winter species that can be unhesitatingly condemned. The summer hawks do little if any damage ${ }^{t}$ and will be discussed under their proper headings. 86. * mourning dove, Zenaidura macroura.

Not uncommon, they were scen in sinall numbers on every visit and as late as Sept. 28, in 1918.

87. * Marsh hawk, Circus hudsonius.

This is the commonest hawk of the locality and ii was seldom that one or more were not in sight. They seemed to have well defined beats over which they worked regularly at stated times of the day. There were several nests in the vicinity of our camp, one of which was ?ound, though later broken up by soine animal of prey of considerable size, as there was evidence of a severe struggle about the nest. $\wedge$

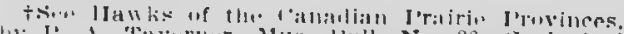

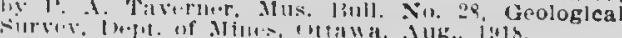

very pretty sight was witnessed several times. One hawk, usually the male, with a mouse or other prey in its talons approached the nesting marsh calling loudly. It was answered by its mate who rose from the nest and came to the call. They circled and manceuvred a minute and then, as the female passed beneath her mate, he dropped what he held and she with a quick reach of her talon, caught it in the air and returned to the nest or an adjoining knoll to feed it to the young or to herself. Sometimes several attempts would be made by the ins birds to get into the proper relative position, but the upper bird never dropped the prey until he was satisfied that conditions were favorable nor, when he did drop it, did we ever see his mate miss the catch. Marsh Hawks were still common when I returned in the autumn of 1917 and when Young left in early October, 1918.

88. *ShaR:-SHINNEd haWk, Accipiter velox.

In 1917, one bird seen on May 25th and other individuals on various days during the September visit. In 1918, Young noted occasional individuals throughout the summer except from June 2, to Aug. 5.

89. Coshawk, Astur atricapillus.

Though no Goshawks were seen in 1917. Young noted two on Aug. 21, 1918 . We received such detailed accounts of the number of "large gray hawks" that visited the country the winter of 1916 . 17 that there could be little doubt as to the identity. Without question these birds together with Horned and Snowy Owls, were the immediate cause of the scarcity of Prairie Chicken, and Sharp-tailed and Ruffed Grouse. This bird is a brush hunter and doubtless accounted for many Ruffed and Sharptailed Grouse in the poplar bluffs by day, while the Horned Owls took many by night tha' roosted in insufficient cover whilst the Snowy Owl that is largely a diurnal hunter scoured the more open places. The trio made a combination that is difficult for any grouse to escape. As mentioned be fore, doubiless these birds came from the north in such unusual numbers in search of food on the depletion of their usual rabbit supplies. To date, February, 1919, we have received no notification of another flight of these birds. On the contrary all reports point towards an increase of rabbits, and a decrease of destructive raptorial birds in the more settled communities, and we assume that it will be several years before the latter become a serious menace again.

90. *RED-Tailed hawk, Buteo borealis.

Next to the Marsh Hawk this was the hawk most often seen. They were shy, though still not quite as wary as the individuals we are in the habit of meeting in the eastern provinces. They nest in some of 
the smallest trees, and those sccustomed to finding Red-tail nests in the tops of the highest and most in accessible trees, are surprised at the low elevations of many of their nests; we found them as low as twelve feet from the ground. A few birds seen were very dark or entirely black, though the six taken in 1917 were of ordinary light type and four of them indistinguishable from eastern birds; only two would have been identified as Western Red. tails, B. b. calurus, if their geographical origin were unknown. Probably some of the birds seen were Swainson's Hawk but except in most typical plumage I fail to see how these species can with cerlainty be separated in life. While it is evident that the Coshawk and the two large owls do serious damage to upland game, little objeclion can be made to these large summer Buteos. Through the spring and summer their main dependence is upon the Gophers and Cround Squirrels and the good they do in this direction can hardly be over-estimated. Though we were not in the Shoal Lake district durng the summer we had special opportunities of stud ig the economic effect of these birds on the Red Deer River in Alberta a few weeks later, where the conditions as $f \mathrm{ar}$ as this aspect of the quastion is concerned are similar. We found them subsisting exclusively upon small destructive mammals. If it is true, as most excellent judges have stated and as was verified to us by several practical farmers, that a gopher will destroy a bushel of wheat in a season, with this grain worth two dollars a bushel, the hawk that takes a gopher a day for three months in the year is of real econumic value to the community and should be rigidly protected. It is true that gephers hole up early in the autumn, after which the Red-tails and other Buteos may turn their attention to other focd supplies, but only after several months of valuable service to man. These birds are peculiarly mammaleaters and usually turn to mice rather than to birds. A few individuals occasionally, under certain conditions, develop a taste for poultry and game, but it is comparatively rare for they have not the speed and energy to hunt such game systematically as does the Coshawk or the rare large falcons. However. it would take a great number of chickens and game to counterbalance the good done by the destruction of noxious rodents, especially in the prairie provinces where these pests are a serious hindrance to agriculture. The farmer and other shooters usually plead their inability to separate one hawk from another as extenuation for killing all birds of prey. In truth, when the stake is so important, a modern agriculturist has as little excuse for not learning to discriminate between bird friend and foe, as he has for failing to learn the obnoxious weeds or insects and the methods for their control. Many, also, fail to judge the relative proportions of the case: they are loud with indignation when a hawk kes a partially grown chick, but fol to inthuse when the same bird prevents the destruction of twenty bushels of grain. While an occasional Gos. hawk does or nay remain in settled conmunitics through the summer the majority of the large sum. mer hawks are Buteos and harnuless. They depart in the autumn whic the cbjeclional ones are mostly winter visitors. Should only winter hawks be killed or such others as are caught in the guilty act, but little mistake will be made.

91. *swat.sson's IIAWk, Bulio s'ainsoni.

Though we failed to idrutify this species specifically in 1917. Young took a specimen on May 23, 1918. It is quite similar in color to the ordinary juvenile Red-tail, but more profusely and evenly spolted over with dark on all below except throat.

92. *BRond-Winged HaWk, Bulco playplerus.

Mr. F. Arnold tells me that he took a set of Broad-winged Hawk's eggs near Woodlands a few miles south of Shoal Iake, June 10 (1895). On May 5, 1918, Young reports flocks of 5 io 10. aggregating 50 or more, passing over rvery twenty minutes or so, all lieaded north. Single individuals were noted on the 8 th and $22 \mathrm{~s}$, and then no more were observed until Oct. 1 and 2, when three and two were seen.

93. *ROUGH-LEGGed IIAWk, Archibul'o sanclijohannis.

Mr. Wm. Ward presented us with a specimen he killed on Oct. 2, 1917, which forms our only record for the locality. These large hawks, characterized by having the legs feathered to the base of the toes. are probably the least harmful and most beneficial to man of all the raptores.

94. BALD CAGLE, Haliaclus leucocephalus.

The $W$ ard brothers told us in 1917 that four years previously a juvenile was taken. They usually see from three to four cagles a ycar.

95. PERECRINE FALCON, $F_{a} ; 0$, peregrinus.

In 1918. Young reports the Duck Hawk $F$. p. anatum, several times in May and again on Aug. 2. The Ward brothers scen to know it and report it regular but not common. It is unlikely that it breeds in the locality.

96. PtCEON HAWk, Falco columbarius.

Young records the Pigeon $\mathrm{Hawk}$ as seen once in early July, several times in late August, and again in September and early October. No specimens were taken but, without doubt, the form is the typical race, $F$. c. columbarius.

\section{7. 'SPARROW HAWK, Falco sparvarius.}

Only occasionally scen in the spring of 1917 and not noted in the autumn, but in 1918 a few individuals noted constantly from arrival April 23 to departure the first of October. 
98. osprey, Pundion haliaclus.

One flew directly over our camp on May 26. 1917. Noted in 1918 by Young, from May 5 to Aug. 6. Said by the $W$ ard brothers to be rare. 99. LONG-EARE.D OWL, Asio wilsonianus.

In 1917 we received descriptions evidently referring to this species and were shown an old nest that seemed corroborative evidence. The supposition is confirmed by Mr. Job who reports finding four young of various sizes in an old crow's nest on opposite side of the lake June 28, 1912.

100. *short-eared owl, Asio fammeus.

The commonest owl in 1917, seen nearly every evening, and often during the day, bealing along the lake shore or over the old reed beds and marshes. In 1918, however. Young only noted single in. dividuals threc times during the entire season, April 30 1o May 15, taking one on May 2.

101. * CREat horNed owl, Bubo virginianus.

In 1917 occasional large owls were glimpsed or heard of during the spring visit ano on Sept. 17th one was $t . " \mathrm{cn}$. It is referable to the Arctic
Horned Owl, B. v. subarclicus, but not absolutely typical and with slight tendencies towards the Western Horned Owl, B.v. pallescens. During the winter of 1916-17 a large Alight of these birds, together wilh Coshawk and Snowy Owls, came from the north, obviously driven inio new fields by the dearth of rabbits. Wirhout doubt the Harned Owls har an appreciable influence in the destruction of upland game; though, as a night hunter, it was probably the least harmful of the trio. Young only noted one individual in 1918, on July 21: by its dales a probable breeder.

102. * SNowy owL, Nyclea nyclea.

From the accounts of the Ward brothers, it is evident that unusual numbers of this species accom. panied the flight of Goshawks and Great Homed Owls in the winter of 10/6-17. Being more of a diurnal and open country hunter than the Horned Owl probably this species was largely instrumental in the destruction of the grouse. In 1918, Young saw individuals from April 30 to May 15, taking one on May 2.

( $T$ o be continued)

\section{THE ARCHAFOLOGICAL VAI.UE OF PREHISTORIC HUMAN BONES}

\section{By Harlan I. Smith, Museum of the Georocical Survey, Ottawa, Canada.}

many children and young people as well as those

Why do we bring so many human bones into a museum? Why is one skeleton not enough? Such questions are always surprising ior it would seem that anyone might think of many reasons why we should collect the bones and why one skeleton wrisin bc as unreprcsentative as one man is unrepresentative of his race. If we were to describe a tall, bearded man and say that he is representative of the English, il would be untrue, for there are short Englishmen and therc are beardless Englishmen. Thesc fcatures of Englishmen are only two of a great many that could be mentioncd. Likewise it is neccssary, if we are to kno: an ancient people, to have enough skclctons to enable. us to obtain average measurements and a representative series for study of the type.

The age at which an individual died can be determined approximately froin his bones. If we have enough skcletons, we can determine how many individuals died in infancy, how many as little children, how many in middle age, and how many lived to be very old. This information regarding a primitive or savage people would be interesting in comparison with the same facls regarding our own people. We are often told that Indians werc very healthy and lived to an old ag: but in archcological plorations we find the bones of a great of old people, showing that many of the Indians died young.

Fairy tales about the bones of giants and dwarfs are common. One can hardly think of a place he has explored where he has not been told of the finding of the bones of a giant, yet giants are very rare and of all the hundreds of skeletons that I have dug up and of the thousands seen in museums, I have yet to find so large a specimen. In fact, the skeletons are no larger than those of the people with whom we daily mingle.

The boncs of children, easily determined, are often mistaken, by those who know nothing of such subjects, for bones of dwarfs.

A human skull that would hold "at least a peck" figures frequently among stories told by people who have probably never dug up a single skeleton, but who tell of what they have seen someone else find. Where all these extraordinarily large skulls are now is a mystery, for certainly they are not to be seen in our excavations, or in museums. The same is true in regard to the stcry of the leg bone of a man, told at practically every place in North America where I have carried on explorations. One end of the bone was put on the ground and the other cnd came nearly to the waist; but such bones 


\title{
THF. BIKDS OF SHOAI. I.AKE, MANITOBA
}

\author{
By P. A. Talehne.r. \\ (Continued from page 164 of Tile. Ottawa Natukat.st, Vol. XXXII.)
}

103. *Biack-BILla d CuCKoo, Coceyzus iruhrophthalmus.

Job reports seeing this species on the western side of the lake on June 27 to 30,1912 . W' siw none in 1917 though we heard rumors of cuctoos having rested in the vicinity. In 1918 the Black-hill appeared on June 14, after which Young noted a few birds almeat daily to August 1.

104. AELTHD KINCEFISIIF.r. Ceruls alevon.

Strangely encuph, col the borders of surh a fine lake we sas no kingfishers in 1917. thouph Young reports enc on May 2, 1918. Thr Ward brothers sily that in previous years there were always a few about, and Seton reports a specinen taken by Miller Christy on May 15, 1887. The only explanation of their present absence secms to he the lack of fish caused by the extreme akalinity of the lake at its present level.

105. *llalky woodpecker. Dryobales vit!osu.

Rather rare. Only two seen during the spring visit ard one in September of 1917. Yeung noted the species, in 1918, in limited numbers, from June 3 to Sept. 26, taking juveniles but recently from nest, so it douhtless breeds in the vicinity. Five of our specimens are clearly reterable to $D$. frucourclas theugh one, Sept. 22. 1917, fall, s!ightly shor! of lencomilas measurenients.

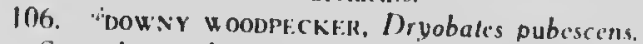

Several seen during the spring of 1917, but none in the autumn. Ohscrved hy Young in 1918 in small numbers from May 3 10 Sept. 12.

107. *VELLOW-BI.LLIED inpscicker, Suphrapicus larius.

Vext to the Flicker the commonest woodpecker. Several nests were found and the species was still present during the fall visit in 1917 and to the end of Septenber, 1918.

108. RED-IIEADFD WoOv'ECKEK, Malonepres Cryllurocephalus.

Though we have no substantiating evidence, the Ward brothers declare that they have seen one or two individuals. There should be but little mistake with such a showy and strongly marked species. 109. *FltCNER, Colaples auralus.

Very conumon and breeding. Still present in 1918 to date of leaving Oct. 2. Young says that through Seplember they were very busy teeding on ant hills. 110. * Nightiawe. Chordciles virginianus.

Very common in 1917. First arrival May 18. Onc secn on Sept. 17, but none thereafter that year.
The specimens taken seem to he lirginianus. One is near'y light enruol to he regarded as hepperis but as it can he naterhed ty individuale from New Brunew'ck and cen'ral On:ario, I hesitate to an identify it.

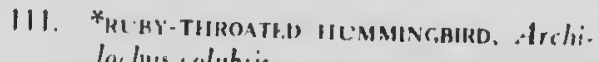
loilus colubris.

Ouite comrasn throughoul the suring viat of 1918 and noted be Yrung occasionally in 1918 from Iune I to cud of Auguat.

112. *wHIP-POOR-W'LL, Antroslomus vocifcrous.

Head in 1917 nearly every night during the qrine bisit ard once in the autumn, on Sept. 17. Yerng only ohserved it once on June 6 in 1918. hut his difficulty in hearing would prevent his noting it very ofien.

113. * KINGAIRI), Tyranners tyrannus.

lirs: sten in 1918 on May 18; very common by th. 29:h. On Sept. 18 a feck of six wer.

Corimru in 1918 from May 1710 Sept. 10.

11. *PHO'AF, Savornis phoebe.

Oute laken by Young. on Aug. 30, 1918, is our only record.

11j. *hestf D Flicatcher, Myiarchus crimilus.

In $1917 \mathrm{cn}^{\prime} \mathrm{v}$ one was secn, June I. In 1918, Yeung, noted it twice in carly lune, three times in Ju'y, and nne in September. The Ward hrothers say that in 1916 Frank McGiffor look a set of cegs Incally.

II3. O'NE.-MDED FLYCATCHER. Nulallornis borcalis.

In $1917 \mathrm{on}$. reported on June 5 and one taken on the 1tith. In 1918 Y'cung noled several on June $f$ In 9. and again a single bird on Aug. 17.

117. *Woon PlWte. Myiuchanes virens.

Cur nnly recerd for this species consists of two specimens takin by Young on June 18 and July 2 . 1918. The former is a female and had an egg ready to lay, thus verifying the species as a breeder in the locality.

118. *yellow-BL.LLied Fiycatcifer, Empidonax Mavin'utris.

One taken on Maple Island above the Narrows on May 30, 1917. As sight records unsupported by the car are unsatisfactary in beriad to the smaller Hycalchers, citing the specimens taken by Young in 1918 is probably the beltcr way of reporting his experience. He took specimens of this species on June $\$$ and Aug. 15. 
119. "Thalle.'s flycatchik, Enipidonax trailli.

First seen on May 9, becoming almost common by the 14th. In 1918 Yound look one on June 8 . All apecimens are referable to the Alder Flycatcher, F. l. alnorunt.

120. *Least flycatchr.r, Eimpidonax minimus.

In 1917 first icen on May 23. By the 30:h they were common in all the bluffs. Young's experience in 1918 seems about similar. He took specinens from May 30 to July 31

\section{1. *iluknid lakk, Olocoris alpestris.}

In 1917 very common during the spring visit, but only a few present in the autumn. In 1918, Young feund them consistently common throughout his stay from late April to early October. On April 24 he found a large fock (100) in company with l.ap). land Longspurs. He obtained one specimen from it, a well-marked $O$. a. alpestris. All other birds taken are $O$. a. praticola. It is worth while noting, us a caution against laking assumed breeding dates as evidence of nesting. that only six days after the taking of the above evident nigrant alpestris nearly fully fedged young of praticola were collected. Thus local birds had ycung out of the nest before more northern nesters had left for their breeding grounds.

122 macpie, Pica pica.

The Ward brothers say that the Magpie occasion: "ly occurs absut Shoal Lake. They recall one seen in July and Iwo in June, 1904. May 21. 1918. William Wiad reported seeing one near camp, and a few days later Frank Ward had exceptional opportunities of watching another at Gimli on the shores of Lake Winnipeg. some forty iniles east of us.

\section{BLLE JAY, Cuanocilla rislalet}

In 1917 fairly common in spring but not noted during the autumn visit. In 1918 Young noted the species until Sept. 28.

\section{Canada jay, Perisorems conadensis.}

Said by the $W$ ard brothers to be a winter visitor, coming sometimes as carly as September, but less numerous of late years.

125. Ralen, Corvus corax.

Said by the Ward brothers to be fairly common during hard winters.

126. *american crow, Conus brachyrhynchos.

Very abundant. Residents do not complain much of its destructiveness to crops but it is certainly a greal nest robber and its effects upon the ducks must be marked and serious. Amongst Young's specimens are two that he concluded from their actions to be mated, but, while the male is large even for c. b. brachyrhynchos, the female falls well within the measurements for $C$. $b$. hespris. Considering other Canadian prairie specimens with these. I do nol connider the Iwo races satisfaclorily differentıated.

127. "aobolink. Dolichonyx oryzivorus.

In 1917 a few were seen on wet meadows in the upring. none in the autumn. In 1918 Young noted them from June 8 to Aug. 22. The residents say thal occasionally they do some damage to srain. 128. "cowbiko, Molothurus aler.

V'ery abundant. Noted by Young III 1918 10 Srit. 7.

129. "Yellow-tifadfd Blackbtad, Konllock. phalus xanthorephalus.

The least common of the resident blackbirds. Oc casional small flocks were found foraping licre and there on the uplands, cultivated fields and dry marshes. In 1918 still scarcer than during the preceding season. It seems that this bird requires more extensive marshes than the Red-wing. In 1917 we found resident colonies in a fer places while the Red-wings occupied every reedy slough. Young reports no breeding birds in 1918. His latrst record for the sp sies is . Iug. 26. The juveniles in first winter plumage are quite similar to the adults but the white primary coverts are reduced to traces and the crown and hind neck conrolorous with the back. In one specimen, a stripped plumage, similar to that of the juvenile Red-wing is just disappearing on the breast where it is being replaced with yellow of rather a deeper orange than that of the adult.

130. * Red-winged blackbtrd, Agelanius phoceniceus.

Very abund int, breeding in every suitable locality.

The A.O. U. Check List recognizes the Redwinged Blackbird of central North America as the Thick-billed Red-wing, A.p. forlis. This race Mr. 1I. C Oberholser (Aul XXIV. 1907. pp. 332. 336) further divides into northern and southern forms. calling the Canadian race $A$. p. arctolegus, extending its range east to Isle Royai. Lake Superior, and restricting fortis to the United States, south frout Nebraska. As the A.O.U. Cummittec has not as yet recognized arctolegus, from the standpoint of the Check List, it can be regarded as a synonym of forlis. The diagnosis for forlis calls for a larger bird than phoenicus, the eastern race, with a comparatively shorter, thicker bill. Arctolegus is characterized by its describer as a large phoeniceus with slight colo: differences in the female.

To obtain easily compared factors of sha. and size, I have divided the length of the bill by the depth for an index of shape and multiplied them logether for an index of size. The former gives the length in units of depth, and the latter a product that whilst more or less arbitrary in itself, when derived from sperimens of the same speries, should be strictly comparable with each other and representative of relative size, irrespective of the disturbing element of shape. 
Comparing Shoal Lake birds wuth other nuaterial, I have made use of the following adult male mates. ial: 9 from Mass., southern Ont. and southern Mich.; 7 from Shoul l.ake and two from Douglas, Man.; and 7 from Sask., Alta., and Mack. The measurements of these birds logether with those sin. larly derived from Mr. Oberholecr's papes above ciled, labulale as follows:

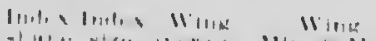

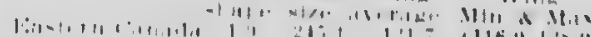

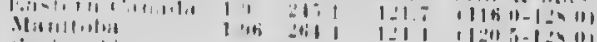

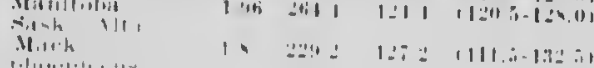

$1 \cdot 1, \ldots+1 \cdot 1,+1+1$

il 11,11,

111, $1,1, \ldots, 1,1\}$

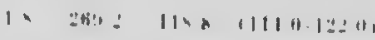

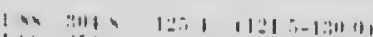

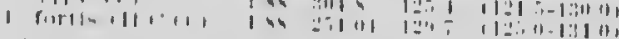

In color. I find Shoal lake feiniles showing a slighily greater annount of white below, most dislinclly of the throat and upper breast, but the dis. linction is too slight and inconsistent for ceptain or individual recognition.

It will be seen that the difference in shape of the bills of these various strains is very slight, and in no case marked enough to warrant the title "Thickbilled", in fact Oberholser's arctolegus and fortis have more slender bills than phoeniceus, and the Shoal Lake specimens considerably exceed all others in this direction having minimum and maximum indices of 1.72 and 2.22 .

It is also evident that whilst there is a sliglıt increase in size of both bill and wing of this species westward over the prairic provinces, the difference is not so marked in the new material as in Oberholser's measurements: also that individual varialion is almost as great as the racial distinction and is one of averages. Icaving the bulk of individual specimens subspecifically unrecognizable by character. Such distinclions do not in the view of the writer form criteria sufficient for systematic stparation and nomenclature. Irrespective of such judgment on the races concerned it is evident that these Shoal Lake birds are just about inlermediale between castern and west plains birds though personally I do not care 10 separale them from phoeniceus.

131. *WESTEKN MEADOW LARK, Sternella neglecta. Very commo: during all visits. The song of the Western Meadow Lark : justly noled. It is one of the most wonderful prairie sounds and its constant repetition and infinite variety is charactcristic of the west. However, eastern ears may be pardoned for a little disap;ointment on first hearing it. If they expect to hear a glorified eastern Meadow Lark song they certainly will be disappointed. While it is a brantifu! preduction it is no: the sung llacy have been accustomed to associate with the coming of spring. It has many charms of its own, but they are not familiar: in fact hardly a note suggests the well remembered voice of the old castem friend and untul its source is traced, sen an experienced ornithologist is apt to wondes as to the idenlity of the singer. It will. I think, lake several scasons expessence with thi. species to build up a new set of ascociatione nd take It to the heart in place of the well belo: eastern harbinger of spring.

132. *hat.Tlinolit: Okto:s, / tcrus galbula.

In 1917, arrived on May 23, common on June 2: not seen in the aulumn. In 1918. arrived on May 16. the bulk disappenred on July 23, and the last one wit seen on Aug. 6.

133. * Resti Plackaind. Fuphogus curolinus.

Not recognized in spring. but one was noted on Sepl. 21, 1917: nol recorded by Young in 1918.

134. *arewl.s's BLACNhikd. Fuphagus cyanocephalus.

Very amundant and nesting in nearly every open bluff. They follow the ploughman about his work gleaning from the newly lurned furrow, and associale commonly with the sheep perching upon their backs and scrutinizing the flecec, probably for lirks. On Sept. 25. 1917. three were taken from rlock. Of these one feniale, seemingly an adult $y$ its completely granulated skull, had the iris reddish-hrown iust flecked with straw. All other specimens taken had the usual straw-colored iris.

135. *BRONZE GRaCKLE. Quisculus quiscula.

In 1917 there was a thriving colony of Bronzed Grackles nesting in the willows just behind the Ward house until persevering work with a shol gun removed them, after which many more allractive birds of less questionable character were able to appropriate the premises. The $\mathrm{W}$ ards accuse them of doing considerable damage by killing young chicks. While I cannot substantiate this charge I have little doubt as to ils truth. None were seen in the autumn of 1917. but Young noted the species as late as Sepl. 27, in 1918.

136. "eleninc crosatak. Hesperiphono ves;irtina.

In 1917 we saw two to four individuals, May 20. 24 and 25 . and secured several specimens. I noted that the bills of these wcre as green as those of summer birds from British Columbia and quite different from the yellow mandibles of eastern midwinter specimens. The difference is probably seasonal rather than subspecific. Unfortunately these are amongst the birds that were lost. In 1918. Young noted three and two Sept. 25 and 30.

137. *Purple finch. Carpodacus purpureus.

None noted during either spring. Two of three were seen on several days in a small growth of hawthorn in september. In 1918. Young noted small nuinbers from July II to Aug. 26, and a single individual on Sept. 25. 
138. ${ }^{*}$ COLdfinch, Astragalinus tristis.

None seen in spring unlil May 27, 1917, after which they became common and were still numrrous in September. Young noted them in 1917 fron April 29 to his departure on Oct. 2.

\section{9. *PINE sIskis. Spinus pinus.}

In 1918 Young noted 5 on June 5, 2 on the $21 \mathrm{st}$. and one Sept. 2t, taking specimens on the first two occasions.

\section{Fs.row Buntixc, Plectrophenax niralis.}

In 1918. Young found large focks on his arrival on April 24. and saw them almost daily until May 24. After this, 5 were noted on the $22 \mathrm{nd}$ and one on the 28th. Specimens taken on April 21 and May 2 are in high breeding plumage.

141. "Lapland loncspur, Calcarius lapponicus. A few seen hetween May 22 and 25. Very abundant in the autumn, occurring in large flocks in the long grass of the old marshes and on the lake shore. In 1918. Young found large Socks on April 24 . but the bulk of the species left after the 30th. One straggler was taken on June $t$. In the autumn the flocks of the previnus year were absent and he noted but one ind:vidual on Sept. 23.

142. *Cifstint-collark.d lovicsple, Calearius ornatus.

A single bird secured on June 6, 1917, and a fiock of seven noted on the 9th. It was not seen by 'eung in 1918. Suton has a specimen laken by Miller Christy in May, 1887, but the Ward brothers are not familiar witl $\mathrm{u}$, ind it is doubtless rather $1 \mathrm{are}$ in the locality or very local in distribution.

\section{3. *Tespre sparrow, Poocactes gramineus.}

Strangely absent both sp. $19 \mathrm{~s}$ in the vicinity of the lake though from the train one was seen a few miles south of Finview. In the autumn of both years they were seen about the $\mathbf{X}^{\prime}$ ard house in limited numbers betwien Aug. 23 and Sept. 28. These hirds are rather large for the eastern race, and though in rather ind "terminate juvenile plumage can probahly be referred to the western race $P$. g. confinis.

144. "̈alanva sparrow, Passerculus sandnielensis.

Very conmon indeed during all visits. The local breeding birds show the bright yllow eye-brow common to the birds of the prairie provinces, and cretainly do not agree with the discribed characters of $P$. s. alaudinus and at present seem without a name. The autumn hirds are slightly darker than sareanna and are hoth with and without the yellow loral sot. I suspect the.t both a lesident and a igrant form are represented, but I do not care to refer them to any sub-species generally accepted at present.

\section{BAiRD's SPARRow, Ammodramus bairdii.}

Though reported by Chapman as very common at Shoal Lake and by Seton as common and breed. ing, the species was carefully searched for both seasons without success. Undoubtedly it has departed from the country with the lowering of the lake level and the disappearance of the broad marshes.

146. *Leconte's sparrow, Passerberbulus lecontei.

Scattered individuals were met with both seasons in widely separated localities both in spring and in autumn.

147. *Nelson's sparrow, Pascerberbulus nelsoni.

The veste:n form. the Prairie Sharp-tailed Sparrow, $P$. n. nelsoni was mel with in scattered individuals in various parls of the surrounding country as late as September 25. The juvenile plumage is quite different from that of the adult and might well be taken for a different species. All strong oclire. slightly paler below and only hroken by restricted luscous centres of secondaries and wing coverts which become fainter and almost concealed across the back, a double crown s!ripe and a faint bar back from the cye. The outer web of thr first primary is edged with clear cream and the lail is ochraccous-fuscous with dark shaft. One specinen shows adult plumage appearing in the juvenile dress indicating that full plumage is assumed the first winter.

148. *HARRIS's sparRow, Zonotrichia quernla

Very common on our first arrival in 1917. Most of them left ebout May 28, though a couple of individuals remained to the end of ou: stay. Frank Ward reported secing one carrying nesting mitterial from his chip-yard towards the nearby bluff and suspected that they were nesting in the lecality. The same authority tells us that some years ago he found a nest of this species on the ground in the shelter of an old lng. On the return visit the same autumn they were common again in their old spring haunts and: was informed that individuals had been noted regularly through the su:nmer. With this possibility of finding brecding birds, Young watched carefully for them during the summer of 1918, but between May 28 and Sept. 14 none were noted. They returned on Sept. If and were till present when he left on Oct. 2. The most peculiar thing about these autumr. birds was the unusual abundance of adults in comparison to jureniles. Of perhays iffy bilds seen but tiuree or four were juvenile either by plumage or cranial cha:acters. This is unusual enongh amongst autumu birds to justify special mention, is usually juveniles greatly outnun. ber aduls.s.

149. "WHITE-CROWNE.d SPARRow, Zonotriclia leucoplrys.

In 1917. single individuals seen on May 15 but 
common th oughout the autumn stay. In 1918, present in limited numbers from May 6 to May 23 and rather more numcrous Sept. 17 1o 30. Of those in adulı plumage, Iwo males (May 13, 1918 and Sept. 20, 1917) have the whitc loral line continuous to hill and can therefore be ascribed to Z. l. gambeli. The orher has it faintly interrupted across the lores and must therefore be regardicd as intermedialc between Z. I. liucophrys and gambeli.

150. WIIITE-THROATFD SPARROW, Zonolriclia aibic ollis.

Common both spring and autumn. In 1918, absent from May 27 to Sept. 8, except four individuals seen on July 24 . Great numbers seen Sept. 19-27. but still present when Young departed on Oct. 2.

151. *TREE sparkow, Spizclla monticola.

Not noted in 1917. In 1918 ohserved fron: April $2610 \mathrm{May} 4$, and again on Oct. 1 and 2. Onc specimen, female. April 30, I refer to $S$. $m$. monticola.

152. * ChIPpisc spakRuw. Spizclla passcrina.

Very cummon in the spring of $191 \%$. Io the end of May flochs of a hundred or more were met. In the autumn the species was not cerlainly iden $i$ fied lheugh the first day of arrival I thought I recopnized them anongst the hordes of clay-colored sparrows. In 1918, Young noled a few on May 4 and 8. From the $161 \mathrm{~h}$ to 27 th it was present in flocks of from 50 to 100 . The species departed on June 8 and no more were seen except 3 on July 23.

153. *Clay-COlorfo sparrow, Spizclla pallida.

Very common in spring and autumn. In 1917. they seemed to lave or Sept. 21, but in 1918. Young noted them to the date of leaving on Oct. 2. 154. "S-ATE-COLORED JUNCO, Junco hycnalis.

In 1917, but one specimen seen in the spring but fairly common in the autumn. In 1918. Young noted it from April 24 to May 15 and from Sept. $610 \mathrm{Ocl} .2$.

155. *song sparrow, Melospiza melodia.

Common in spring and aulumn of bolh years. In 1918, preset.t on arrival, April 24, and when leaving. Oct. 2. Specimens taken between May 13 and July 31, probably breeding birds are the slightly lighter form, will more distinct markings, than eastern $M . m$. mclodia and 1 refer them to $M . \mathrm{m}$. juddi.

156. "LINCOLN'S SPARRow, Melospiza lincolni.

In 1917, single individuals secn and laken on May 19 and June 1 . In the autumn seen nearly daily in limited numbers. Noted in liniled numbers by Young in 1918 from May 11 to 25 and more commonly from Aug 3 to Oct. I.
157. *swamp sparrow, Melospiza gcorgiana.

Seen in small numbers in the spring of 1917 and more commonly in the autumn. In 1918, Young noled it from May + to 30 and again Aug. 21 to Oct. 2. Sirangely cnough but one bird was secn in the summer. June 10, which seems to indicale that the specics does not breed in the locality.

158. *Fox sparrow, Passerclla iliaca.

One specimen taken Sept. 22 is all that was seen in 1917. In 1918, Young noted single individuals on Sepl. 16, 24 and 30, and a flock of 30 on the 25 ih.

159. *TowhEE, Pipilo erylluroplhalmus.

In 1917, fairly common in the spring and still present Sept. 19 and 21. In 1918, Young saw a few individuals with general regularity from May 24 to July 29. A single bird. Aug. 13, and another Sept. 19.

160. *Rose-breasteu concbea:., Zanuclodia ludoviciana.

Fairly common during the spring visit in 1917 ln 1918 cbserved irregularly from Ma." 16 10 Aug. 5.

161. *plerple martin, Progne subis.

A few seen daily in 1917, probably the same oncs. A few occupied a box near an adjoining summer coltage and another colony was found nesiing according to aboriginal habit in a hollow tree a few miles from camp. In 1918, noted by Young from May 17 to Sept. 20.

162. *CLiff swallow, Petroclielidon lunifrors.

In 1917 a few scen daily with the flocks of Barn Swallows about camp and occasional birds elsewhere. Selon noted iwenty-five nests on a barn in 1891. In 1918, noled from May 24 to Sept. 17.

163. * Bakn swallow, Hirundo erylhrogasler.

Small colonies occupy most of the farm building groups in the neighborhood. In the autumn of 1917 this was the only swallow seen. In the chilly mornings a small flock of them would be found warming themselves on the sunny roof of the house where the fresl was melting. As soon as the day warmed they disappeared over the meadows and rarely returned until the next morning. The last seen were on Sept. 21. In 1918, they remained common until Sept. 20.

164. *REE. SWALLow, Iridoprocne bicolor.

I 1917 , only a few seen each day in spring and none in the aulumn. In 1918, they remained common unlil Aug. 21, but a few were scen thereafier until Sept. 17.

165. *Bank swallow, Riparia riparia.

A few observed daily it. the spring of 1917. The Ward brothers say that onc stage of the lake left numerous steep hanks five to six fect high and that swallows nested in these in great numbers. Now 
these banks are far removed from the water, cut down by cattle and sheep, and are deserted by the birds. We saw no nesting places in the vicinity. Young noted it in 1918 only in autumn, arriving on Aug. 17, and seen in small numbers irregularly until Sept. 12.

166. * Cldar waxwing, Bombycilla cedrorum.

In 1917, a flock of a hundred or so seen on May 11 and smaller lots daily thereafter through the spring visit but not noted in the autumn. In 1918, the species was first seen on June 4 th and irregularly observed until Sept. 26.

167. * loccerhead Shrike, Lanius ludovicianus.

In the spring of 1917 we found two breeding pairs and a single itdividual. I can find little foundation for Ridge vay's color distinction, "decidedly paler" of the White-rumped Shrike, L. I. cxubilorides. Prairie birds are very slightly paler than $L$. $m$. migrans from eastern Ontario. The difference can only be observed by the closest com. parison. In the four specimens taken at Shoal Lake the rumps are intermediate between that of eastern birds and excubitorides from Alberta. I, Iherefore, regard them as intermediates between these rather poorly defined races.

168. *RED-EYED ViKEO, Vireosylva olivacea.

In 1917, not seen until May 30 after which occasional birds were noted. Not seen that autumn. In 1918, Young noted the species continuously, in fair numbers from May 17 to Sept. 16.

169. *philadelphia itreo, Vircosylva philadelphia.

Not noted by us in 1917, but Seton has a specimen in his collection taken at Shoal Lake by Miller Christy on May 20, 1887; Young collected specimens on the following dates in 1918. May 21 and 24, June 1 and Sept. 24.

170. *WARBLING vireo, V'ircosylva gilva.

In 1917, quite common after May 28. In 1918, Young found it constantly present in fair numbers from May 20 to Sept. 26. All specimens are $V$. g. gilva.

171. *solitary vireo, Lanivirco solitrius.

Not noted by us in 1917, but seen by Young in 1918 from May 10 to 20 and Sept. 2 to 16.

172. *BLACK AND WHITE WARBLER, Minotillo varia.

In 1917, nccasional individuals seen after May 30 in spring and one on Sept. 19. In 1918, Young noted it with fair regularity, but scarcer in July, from May 8 to Sept. 26. It probably breeds.

173. *NashillLe. Warbler, l'ernivora rubricapilla.

Not noted in 1917 but reported by Young in 1918 to be very common in May and September. Noted May 18 to June 20 and Sept. 2 to 26 with occasional individuals through July.

174. *OKANLE-CROWNED WARBLER, Vermivora
celala.

In 1917, seen the first two days of our spring visit and on Sept. 19. In 1918, Young noted it only from May 17 to 24 . In specimens obtained the yellow is slightly lighter than in comparable eastern species, but as this is probably due to the cleaner and better condition and make up of the skins, I regard them as $V$. c. celata, the geographical probability.

17j. *TENNESSEe warbler, Vermivora peregrina.

Not noted in 1917, but reported by Young in 1918 to be very common in May and September. Noted May 18 to lune 24 and Sept. 2 to 26 with occasional individuals through July.

176. *CAPE MAY warbler, Dendrioca tigrina.

Two taken at Maple Island on May 30, 1917, and noted by Young on May 21 to 24, 1918.

177. *Yellow warbler, Dendroica aestiva.

In 1917, a few present is, uur arrival on May 17 but common after June I. Is 1918, common from May 8 to Sept. 16. Compared with the writer's experience with this species in southern Ontario this is a very late stay for the species as in the Lake Erie neighborhood Yellow Warblers are rarely seen after Sept. I.

178. *MYrtle warbler, Dendroica coronata.

In 1917, the commonest Warbler on both visits. In spring i: disappeared atout Jun 1, after which but occasional individuals werc seen.

179. * Macnolia warbler, Dendroica magnolia.

In 1917, rather scarce in spring. In 1918, on the contrary. Young found it quite cummon from $\mathrm{Mi}_{\mathrm{*}} \cdot 16$ to the $27 \mathrm{th}$ and in the late autumn from Sepi. 2 to 28.

180. ${ }^{*}$ Chestnut-sided warbler, Dendroica pensyluanica.

Individuals seen June 4 and 5 and on Sept. 17.

Not scen by Young 11. 1918.

181. * Ray-Breasted Warbler, Dendroica caslanca.

In 1917, only seen on June 2 and 6 . In 1918, only noted on Sept. 6 to 1.

182. *BLACK-POLLED WARBLER, Denćroica striala.

In 1917, first seen on May 30. Quitc common on June 2, and but occasional individuals the:eafter. One seen on Sept. 17.

183. *blackburnian warbler, Dendroica fusce.

One taken by Young on May 16, 1918 is our only record.

184. *BLACK-THROATED GREEN WARBLER, Dendroica virens

Individuals seen by Y'cung on May 24 and Sept. 4, a specimen being taken on the latter date. He also reports the remains of another impaled by shrikes without giving date. 
185. *PaLm warbler, Dendroica palmarum.

In 1917. present in limited numbers on our arrival but none seen after May 25 . Several seen between Sept. 19 and 22. In 1918, noted by Young from May 8 to 30 and Sept. 6 to Oct. 2, the date of departure.

186. *OVEnBIRD, Sciurus aurocapillus.

In 1917, a few single individuals were heard and seen in the deeper woods from May 29 on. Before leaving they become slightly more common. In 1918, roted by Young from May 21 to June 3, one individual in July, and then again from Sept. 2 to 14. This is a retiring species and oftener recognized by ear than sight. Its absence through June, July and August is probably more apparent than real.

\section{7. *NORTHERN WATEK THRUSH, Sciurus nOVC- boraccnsis.}

In 1917, two water thri nes were seen, perhaps an original pair, May 1 and June 2, in the dry willow grown creek bed by the Ward house. On Sept. 19 another was noted in the same locality. In 1918, the species was noted with daily regularity from May 10 to 25 and Sept. 4 to 26, with a single individual on Aug. 22. The specimens are in a very mixed lot of plumages, and one a male, Sept. 12, is nearly as white below as a Louisiand Water Thrush, S. molacilla; two other specimens are nearer the eastern one $S$. n. noveboracensis than $S$. n. nolabilis. Three others while yellower below and blacker above and characteristic nolabilis are quite comparable with some New Brunswick birds. I find that Grinnell's Water Thrush rests upon very inconstant characters.

188. *CONNECTICUT Warbler, Oporornis agilis.

On June 4, 1917, one bird was seen under excellent conditions for determination, when shot it fell far away in heavy brush and coutd not be found. Onc juvenile was taken by Young on Sept. 16.

IE9. *mourning warbler, Oporornis pliladelphia.

Several times in the spring of 1917 I thought I heard this bird in a slashing in the oak patch in the big bluff behind the camp. It kept so close to a limited locality that 1 have no doubt that it was nesting nearby. It was absolutely identified June 14 when secured. In 1918, the species was noted by Young from May 30 to June 8 and one was taken Sept. 7. Specimens of this species in fall plumage arc rather scarce in collections as it usualiy drifts thiough very inconspicuously early in the autumn.

190. *MaryL: vd yellowthroat, Gcolhlypis trichas.

Quite common after June 2. In the aulumn individuals were seen Sept. 21 and 22 . The species obtained are referable to G. $t$. occidentalis, the
Western Yellow Throat. The backs are faintly lighter than eastern and intermediate between them and individuals from Indian Head and Edmonton, but the white foreheads are decidedly more extensive than in eastern species.

191. *WILson's Warbler, Wilsonia pusilla.

Only seen in 1918 on May 18. In 1918, Young observed the species on May 16, 18 and 24.

192. *CANADI is warbler, Wilsonia canadensis.

One taken on June 6, 1917, and noted by Young on May 24 and June 4.

193. * Redstart, Sctophaga ruticilla.

Not seen in 1917 until May 29, but common thereaiter. In 1918. Young observed it from May 18 to June 8 and from Aug. 26 to Sept. 27. He did not note it through the summer.

194. *american PIPIT, Anthus rubcscens.

In 1918 fairly common during the early days of our spring visit along the lake shore, but none seen after May 30. Abundant in the fall occurring in large flocks, scattered bunches and individuals on all bare ground. In 1918, noted by Young on May 13 and 27 and Sept. 14 to date of departure Oct. 2. 195. *SPRAGUE's PIPIT, Anthus spraguci.

Between June 5 and 9, 1917, I was much puzzled by an oft repeated and haunting bird song that could be barely heard and which 1 was unable to locate or recognize. It was a fine silvery gradually descending Ree-ree-ree-a-ree-a-ree-a-aree-aree of about eight notes, and an octave in range. It had a peculiar ringing jingle like the Veery but more sustained and regular. After innumerable futile attempls at discovering the singer at last I found it high over head flying about in circles for minutes at a time. It beat its wings vigorously against the slight breeze, r.aking altitude rather than headway, and then the song came down. After the first two cr three syllables reachcd the ground the wings fixed and the bird would sail in a downward spiral through the remainder of the song. This was ... peated time and time again. It took considerable patience to watch the little vocalist until it came down to earth by an almost straight dive. Though nearly out of sight in the air the speed with which it dropped and the distance away at which it alighted indicated that it was originally up no more than a hundred yards or so while singing. Thereafter we could hear this song nearly the whole of every fine day, but this was the only bird of the species that we met. In 1918, Young reports the species occasionally throughout the summer from June 21 to
Sept. 7 .

196. *CATBiRd, Dumalclla carolinensis.

Common, found in nearly every bluff. In 1918, Young noted it almost daily from May 20 to Sept.
11. 
197. FROWN THRASHER, Toxostcma rufum.

Fair'y common. At leas' two pars lived within hearirg of our eamp in 1917 and we met with half a dozen more on our spring rambles. In 1918. Young noted it constantly from May 16 to Aug. 24 with a couple of late individuals on Sepl. 12 and 17.

198. *ItOLSE. WREN, Troplodytes aedon.

Very abundant and heard singing cverywhere. They do not seem as inelined to build about the farm buildings as the speeies does in the east. There were innumerable possible nesting places about the farmsterd tlat few eastern wrens could resist yet none of them were occupied. A few individuals were stiil present during the autumn visit. In 1918, Young noted it continuously and regularly from May 10 to Sep:. 30. Specimens are distinetly $T$. a. parlemani.

199. *WINtEk WRE, Nannus hicmalis hicmalis.

Not seen in 1917, but in 1918 Young observed single individuals from May 20 to 23, and on Sept. 16.

200. *IHORT-BILLED MARSIt WRE.N, Cistothorus stcllaris.

Not uncommon in cerlain localities. While usually in!.ub: "ling damp marshes some were inund in diy grass or even in brushy edges in typieal House Wren ground. None werc certainly reognized in the fall of 1917 though Young lists it occasionally from June 1 to Sept. 25.

201. *oNG-BtLled MaRSt wREN, Telniatodytes palustris.

Hardly commoner than the Short-bill and not so widely distributed. This speeies requires wetler and more extensive su nps than that specics and the drying up of the murshes would more severely limit i.s habilat. A Marsh II'run glimpsed on the shore of a sinall pond on Sept. 19, 1917, was supposed to be of this speeies. Owing to theil more restrieted habilat the Long-billed Marsh Wren was, in 1918, even searcer than the previous year. Young only records oceasional individuals May 7 and June 10. Specimens show the light back, and brow'n rather than black head of $T$. p. iliacus.

202. "BRow: CREEPER, Certlia familiaris.

Young took two specimens of the Brown Creeper on Sept. 23 and 26, 1919.

203. *RED-BRE.ASTED NLthatcI, Silla canad'nsis.

One individual seen by Young on Sept. 24, 1918.

204. "Black-Capped chickadee, Penthestes atricapillus.

Only seen in 1917 on May 20 and Sepl. 26. Of the former one female was taken with an egg in oviduct ready for deposition. Scattered individuals noted by Young throughout the summer of 1918 . Specimens takell have constantly longer tails than any but extreme eastern specimen and henee are referred to $P$. a. septentrionalis.

205. *Ruby-Crowned kinclf.t, Regulus calendula.

In 1917, single individuals seen May 20 and June I. In $S$ rinmher a few were seen neariy every day. In 1918, noted by Young daily from May 7 to 24 and Sept. 9 to 30.

206. "WILson's thrusH, Hylocichla fusceserns.

Common. Its go!den chain song could be heard every evening from our eamp. In 1918, Young recorded it nearly every day from May 9 to Sept. 28. All speeimens show the slighlly olive back of the Willow Thrush, $H$. f. salicicola.

207. *A'tCE'S THRLSH, Hy/nriclilu aliciae.

Thrushes of this genus were fairly common during migrations, but the bush was generally so dense and the birds so shy that colleetion gave the only certain separation bets cen Alice's and Olive-baekcd Thrushes. I was fairly eertain that we had speeimens of both in the spring eollection of 1917, but they all were lost in transit. One speeiruen taken by Young on Sept. 19 belongs to this species.

208. *OtWE-BACKED TIIRUSIt, Hylocichla ustulata.

In 1918. Young noted thrushes under this heading from May 15 to June $I$ and Sept. 6 to 20. All his specimens except one mentioned under previous heading are of this species which is probably the more common. We have specimens of the following dates: juvenile and adult males Sept. 18, 1917, Sept. 6 and 9, 1918; and juvenile females Sept. 9, $i 718$. These four are slighliy but consistently more olivaceous (or grayer) above and rather more heavily spotted on breast than comparable eastern $H$. u. snainsoni differing from them almost as much as the Willow Thrush, H. f. salicicola differs from the Vecry, H. f. fuseescens. I find these same d.s.inetive eharaeters in an autumn specimen from as far west as Jasper Park but not in spring and summer birds from intermediate points. These specimens agree elosely with the description and range of $H$. u. alnac Oberholser, and if every perceptible difference is regarded worthy of a separate name this form probably has clain to reinstatement in the Check List.

209. *hermtt thrusi, Hylocichla guttata.

Quite common during the spring of 1917. The last specifically reeognized was on June 2 . In the autumn one was taken on Sept. 19. In 1918, Young noted the Herm: Thrush from May 13 to 24 and Sept. 3 to 30. These are of course castern Hermit Thrush, H. g. pallasii.

210. "MertCaN robtn, Planesticus migratorius.

Common on all visits, in 1918, at date of departure, Oet. 2.

211. *BLlebird, Siala sialis.

Though not known by the Ward brothers as a 
bird of the locality, we took a pair in 1917 on May 28 , and later some six individuals were seen at various times in the neighborhocd. In 1918, Young saw 2 and 7 birds on June 24 and 25 . On Oct. 2 as he was leaving there was a migrational wave of the species and he lists 50 for that day. This suggests that far from Shoal I ake being the most northem extremity of the species range here there is a habitat beyond that is occupicd by them in considerable numbers. The species is apparently sprecding into this country.

\section{ADDENDA.}

Since the publication of the earlier parts of this paper the following published data on the birds of the locality have been called to my attention in
Recen: Bird Records for Manitoba by E. T. Seton. luk, XXV, 1908, pp. 450-454.

20. (antea) B:ACK DLCK, Anas rubripes.

Mr. Siton here reports another Shoal Lake specimen of this species in his collection taken by Gro. H. Mercham in 1901 who reports "iwo or incre wire shot at Shoal Lake in 1899".

28. (anlca) woon DUCK, Iix sponsa.

Seton says: "G. H. Meacham reports it rare at Shoal lake, but one or two are seen there each y"ar".

212 LE.AST I IIKN, Ixobrychus cxilis.

Se:on says: "Frank M. Chapman saw one at Shoal I.ake, June, 1901".

\section{BRIEF REPORT OF THE OTTAWA FIFID-NATURAIISTS CI.LB FOR THE YEAR ENDING MARCH 18, 1919.}

The forticth year of the existence of The Ottawa Fie'd Naturalists' Cluh has been the most suecessful. recent history of the society. The clab activities are direeted toward popularizing and diffusing $\mathrm{kn} \cdot \mathrm{w}$.ledge of the natural sciences, and have been carried on in threc chief ways: a course of lectures. two series of field excursions, and the publication of The Ottawa Naturalist.

The club membership now numbers 540 . Twentyone members serving overseas have been carried gratis.

The lec:ure programme consisted of seven scheduled lectures and a special lecture on wild geese by Mr. "Jack" Miner. of Kingsville, Ontario. The lectures are planned to create a more intelligent interest in Canadian naiural history, and to give a betier urd restanding of the value of seientific work.

The fie'd excursions were well patronized, especially the spring series at which the attendance averaged 38 . Weather conditiens reduced the attend?nce at the fall scrics. The spring series $r \mathrm{cn}$ sisted of five cutings and the au:umn series of thrce cutings. Scientific men attended the excursions to direet interest and answer questions.

Tite Crtawa Naturalist, the official organ of the Club has been enlared in dimensions and improved in material qualities and by the intreduction of a cover d sign, more illus'raticns and more articles of Jominien-wide interest.

At the request of several natural hisiory socictive of the Dominicn, a plan of affiiation has been arranged. the magazine of The Onawa Field-Natural'sts' C'ub to be the midium of publieation.

The officers and committees for the year 1919 are as follows:

Presdnt, M. Y. Willı.ns; Viec-Presidents, L. D. Burling, P. A. Taverner; Secretary. Clyde L. Patch; Trrasurer, F. W. Waugh; Editor, Arthur Gibson.
Additional members of Ccuneil: Hoyes loloyd; W. T. Macoun. G. A. Millar, R. M. Anderson. I. M. Macoun. Miss M. F. Cowan, Miss Cranupe, C. B. Hutchines, C. M. Sternherg, H. I. Smith. H. MeGillivray, H. B. Sifton.

Standivg Committefs of Council.

Publications Clyde 1. Patch, A. Gibson, P. A. Taverner, 1. D. Burling. H. B. Sifton.

Excursions - F. W. Waugh, H. B. Sifton, C. M. Sternherg. G. A. Millar, Miss M1. F. Cowan, C. L. Patch, H. McGillivray, C. B. Hutchings, Miss Crampe.

Leclures J. M. Macoun, P. A.Taverner, L. D. Burling, W. T. Macoun, G. A. Millar. R. M. Anderson.

Trust Fund: W. T. Macoun, C. Gordon Hewitt, H. M. Ani.

Auditors J. Ballantyne. I:. C. Wight.

I.EADERS AT Excursions.

Archarology Harlan 1. Smith. F. W. Waugh, W. J. Wintemberg, Dr. C. M. Barbeau, Dr. E. Sapir.

Bolany- G. A. Millar. W. T. Macoun, J. M. Maccun. Mrs. A. F. Brown. Dr. M. O. Malte, I. R. Dymand, E. C. Wight, 11. B. Sifton, Miss M. F.. Cowan.

Enlomoloyv C. B. Hutchings, Arthur Gibson, Dr. C. G. Hewitt, J. M. Swaine, I*. W. L. Slad'n, Miss Crampe.

Goology Dr. F. M. Kindle, Dr. W. Y. Williams, H. McGillisay, L. D. Burling, E. Poitevin, Dr. M. F. Wilson.

Ornillology P. A. Taverner, C. L. Palch, Dr. M. Y. Williams, A. G. Kingston, Hoyes Lloyu.

Zoology - Dr. R. M. Anderson. A. Ha!kett, E. F. Lemicux, E. A. 1.eSueur, C. H Young, C. E. Jchnson.

Photograply -W. S. Hulton. 


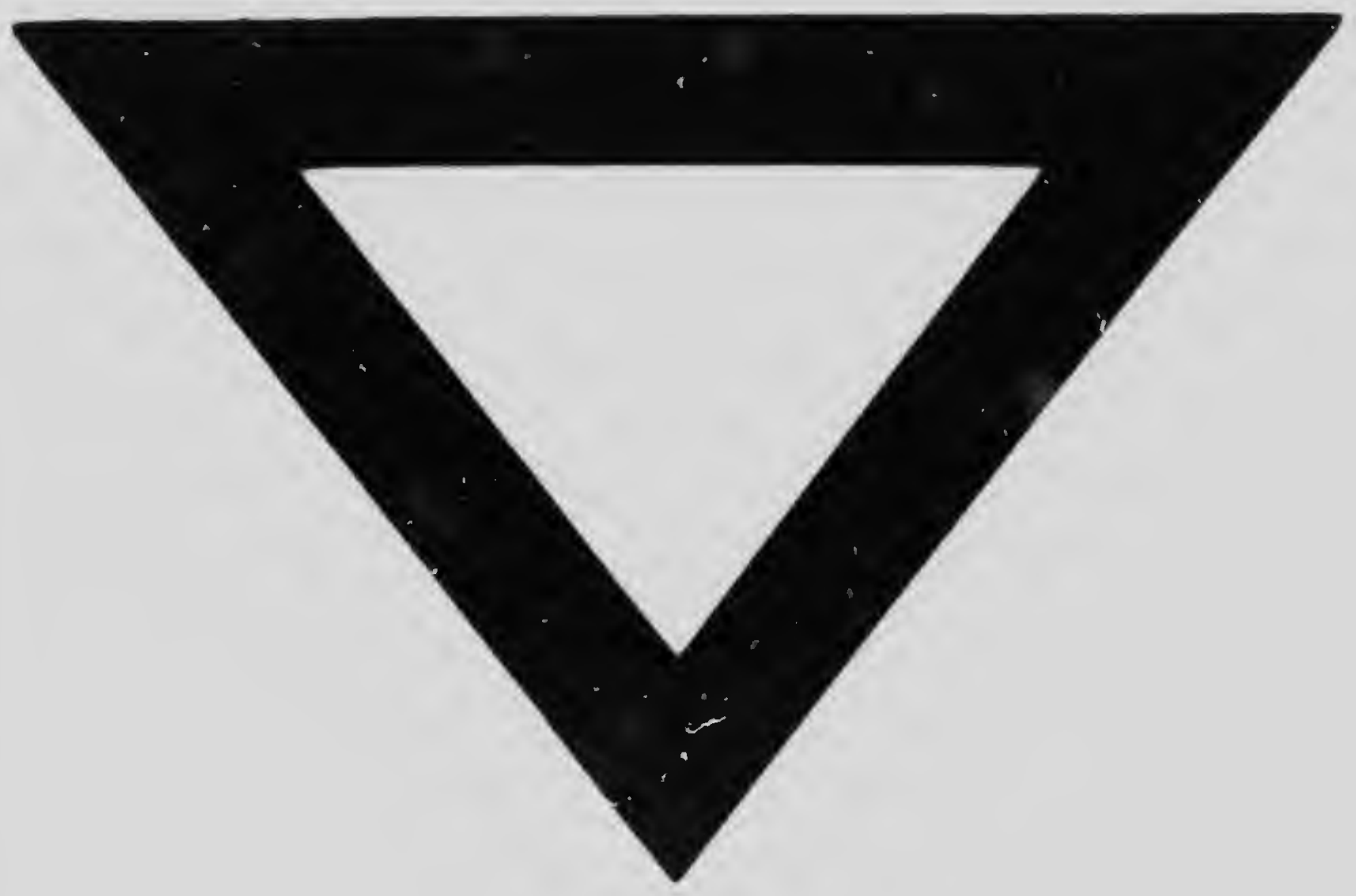

